\title{
THE COMMERCIAL HYPERBOLE OF URBAN EXPANSION AND ITS ENVIRONMENTAL IMPLICATIONS
}

\author{
a hipérbole mercantil da expansão urbana e suas implicações ambientais
}

\author{
Lucas Barbosa e Souza *
}

\begin{abstract}
Resumo
A conjuntura formada pelo avanço da fronteira agrícola brasileira, pelo consequente e franco processo de urbanização do território e pelas recentes políticas públicas federais voltadas ao setor habitacional, tem feito com que as principais cidades do Estado do Tocantins apresentem uma expansão urbana por vezes exagerada. A cidade de Porto Nacional, por sua vez, constitui um notório exemplo desse fenômeno. Tal expansão urbana tem sido baseada em um caráter mercantil excessivo, levando a um parcelamento do solo, por intermédio de loteamentos, que nitidamente ultrapassa a demanda local por novas moradias. A deliberada aquisição de terrenos urbanizados assume a forma de prática especulativa, conduzindo à formação de vazios urbanos. Os principais agentes envolvidos na implantação desses loteamentos adotam estratégias capazes de maximizar a extração de renda da terra, em detrimento de critérios técnicos de ordem urbanística e ambiental. Com o auxílio de ideias oriundas tanto da Geografia Humana quanto da Geografia Física, o presente artigo busca realçar as ligações entre esse modelo de expansão urbana e os impactos ambientais decorrentes. Logo, são problematizadas as atuais e as potenciais consequências negativas à qualidade ambiental urbana, tomando a cidade de Porto Nacional como referência empírica.
\end{abstract}

Palavras-chave: Loteamento; Especulação imobiliária; Vazios urbanos; Impactos ambientais urbanos.

\begin{abstract}
By consistent and clear urbanization process of the territory and the recent federal public policies aimed at the housing sector, the conjuncture formed by the advance of Brazil's agricultural frontier has sometimes presented exaggerated urban expansion in major cities in the State of Tocantins. The city of Porto Nacional, in turn, is a notorious example of this phenomenon. This urban expansion has been based on an excessive commercial character, leading to an allotment of the ground, through the division of the land into lots, which clearly exceeds local demand for new housing. The deliberate purchase of urbanized land takes the form of speculative practice, leading to the formation of urban voids. The key players involved in implementing these housing areas adopt strategies to maximize the extraction of income from the land to the detriment of technical criteria for urban and environmental order. By using ideas derived from both human and physical geography, this article seeks to highlight the links between this model of urban expansion and environmental impacts. So, the current and the potential negative consequences of urban environmental quality are problematCized, by taking the city of Porto Nacional as empirical reference.
\end{abstract}

Key words: Housing area; Real estate speculation; Urban voids; Urban environmental impacts.

\begin{abstract}
Resumen
El contexto formado por el avance de la frontera agrícola en Brasil, por el consecuente y franco proceso de urbanización del território, además de la reciente política federal del gobierno acerca del sector de habitación, ha conllevado las grandes ciudades del Estado de Tocantins a presentar una la expansión urbana a menudo exagerada. La ciudad de Porto Nacional, a su vez, es un ejemplo notorio de este fenómeno. Dicha expansión urbana se ha basado en un carácter comercial excesiva, lo que conlleva a la división de la tierra, a través de los parcelamientos, que supera claramente la demanda local por viviendas nuevas. La compra deliberada de suelo urbanizado toma la forma de una práctica especulativa, lo que conlleva a formación de vacíos urbanos. Los principales actores involucrados en la implementación de estas parcelaciones adoptan estratégias capaces de maximizar la extracción de renta de la tierra en detrimento de criterios técnicos del orden urbano y ambiental. Con la ayuda de las ideas derivadas de la Geografía Humana y Geografía Física, este artículo pretende dar a conocer los vínculos entre este modelo de expansión urbana y los impactos ambientales relacionados. Entonces, son problematizadas la actual y las posibles consecuencias negativas para la calidad ambiental urbana, tomando la ciudad de Porto Nacional como referencia empírica.
\end{abstract}

Palabras-Clave: Parcelación; Especulación inmobiliaria; Vacíos urbanos; Impactos ambientales urbanos.

(*) Lecturer, Doctor of the Federal University of Tocantins (Universidade Federal do Tocantins) - Rua 3, Quadra 17, Lote 11, s/n Setor Jardim dos Ipês, CEP: 77500-000, Porto Nacional (TO), Brasil. Tel/Fax: (+55 63) 3363-0552 / 3363-0540 - lbsgeo@uft.edu.br 


\section{INTRODUCTION}

As a frontier for agriculture and capital, the State of Tocantins has been noteworthy for the significant contribution of investment in recent years, together with the implementation of an infrastructure especially dedicated to the modes of transport and power generation. This has created a scenario that favors a highly technical commercial agriculture, as well as the production, and more recently, the processing of agricultural products, such as soya. In some municipalities, this trend has helped attract companies and labor specializing in different areas of agribusiness. There has also been a gradual consolidation of other sectors, such as the retail and wholesale trades and the provision of educational, financial and health services, in addition to public services at state and federal levels (BESSA; CORADO, 2011). Thus new consumer markets and new demands are formed, which are capable of altering the geographic space even further. This is, in fact, a new stage of urbanization, which Santos (1994) calls the urbanization of territory, a result of the expansion of the technical-scientific environment to the interior of the country, confirming the trend this author has been pointing to for more than two decades.

As they advance towards the interior of Brazil, these transformations install themselves progressively over a foundation that has been historically characterized by archaic political arrangements and practices, and by relationships of power and privilege through which individual interests are imposed on the interests of citizens as a whole. In this way, two realities merge in a geography in which old and new end up communicating, in a discourse of a false development. In this context, the practices of the reproduction of capital rely recurrently on omissive regulation and an opportunistic intermediation on the part of the public authorities, resulting in social and environmental costs incurred by the community, especially the poorer groups of the population.

At the same time, in recent years, national circumstances have strongly favored the expansion of cities, notably through the stabilization of the economy, the reduction of interest rates and the increase in real estate credit, the incentives from housing policies and creditor-friendly legal regulation. This situation is connected to the introduction of financial practices in the context of the production of Brazilian urban space, especially in the case of the metropolises (SANFELICI, 2013). However, traces of this process have also been glimpsed in small and medium-sized cities, including those located in the interior of the country, as exemplified by land reserve strategies, the mercantilist exacerbation of urban expansion through subdivisions and the exaggerated offer of financed lots (SANTORO, 2012).

The confluence of these relatively recent scenarios has caused the property market to heat up in many municipalities in Tocantins, such as Porto Nacional (Figure 1). This city lies 60 kilometers south of Palmas; in 2014 the population was estimated at 51,846 inhabitants, according to data from the IBGE (2014). In fact, the settlement dates back to the colonial era, (XVIII Century), when gold miners arrived in the Upper and Middle Tocantins (IBGE, 1958). In the XIX and XX centuries, prior to the creation of the state of Tocantins in 1988, Porto Nacional was an important city in the north of the state of Goias. Currently, its population is ranked fourth among the municipalities in Tocantins, making it an example of the aforementioned territorial and urban changes that suffers from the unwanted impacts of a rapid capital-driven modernization process.

In 2001, the municipality was affected by the construction of the Luis Eduardo Magalhães Hydroelectric Power Plant, as its urban area was delimited by the reservoir created by damming the Tocantins River. More recently, Porto Nacional has figured among the main municipalities producing soybeans in the state, it is served by a multimodal yard linked to the North-South Railway, in addition to having public and private higher education institutions. These circumstances reverberate in its urban area, especially with the implantation of new real estate subdivisions (Figure 2).

On one hand, due to the reality presented above, at a regional and local level an explicable increase in the demand for urban housing is apparent, but there is also an enormous speculative interest in urban land. On the other hand, as already stated, there are a series of real estate incentives 


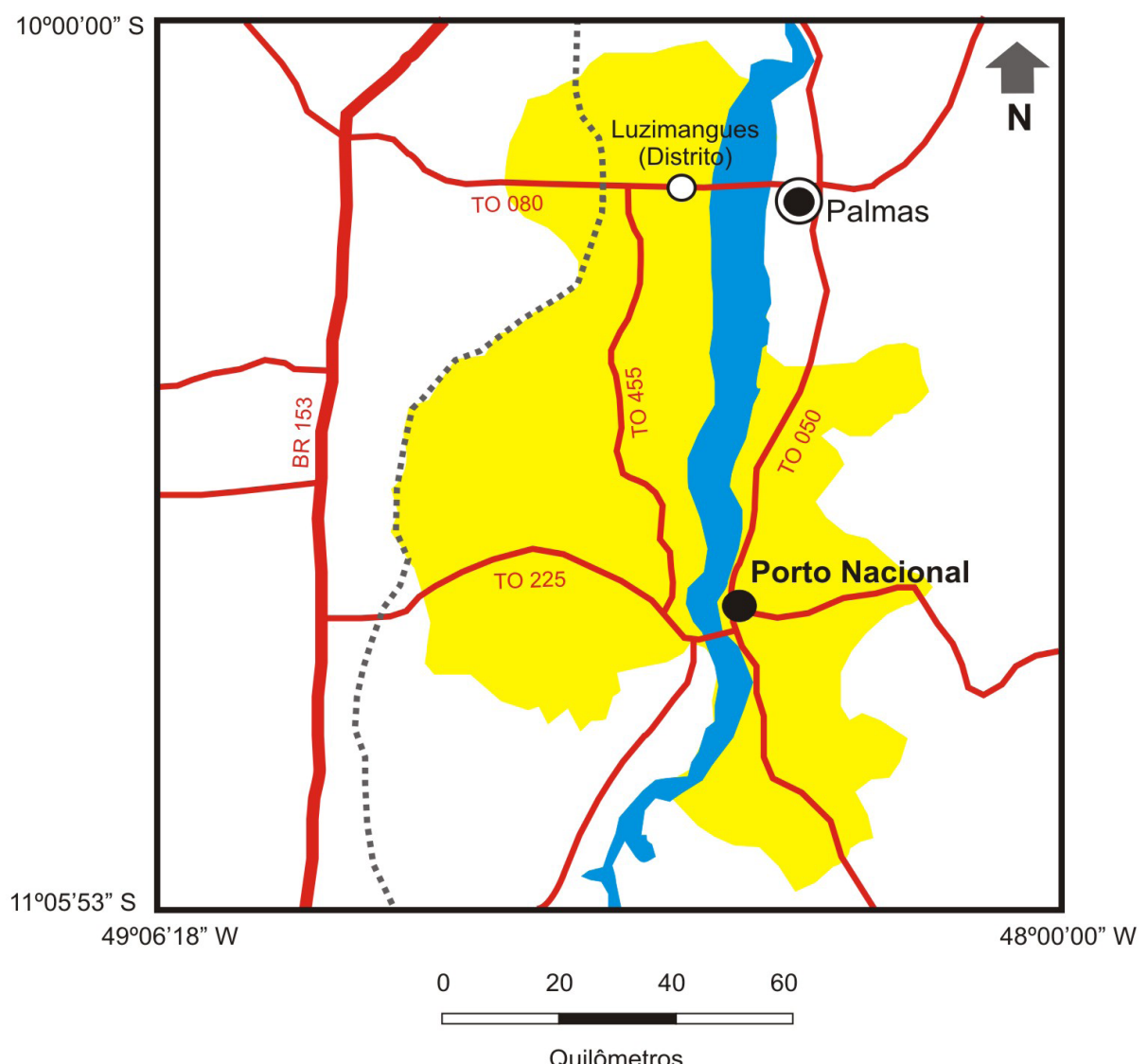

Rodovia federal

Principais rodovias estaduais

Ferrovia Norte Sul

Rio Tocantins (Reservatório UHE Luis Eduardo Magalhães)

Área do Município de Porto Nacional

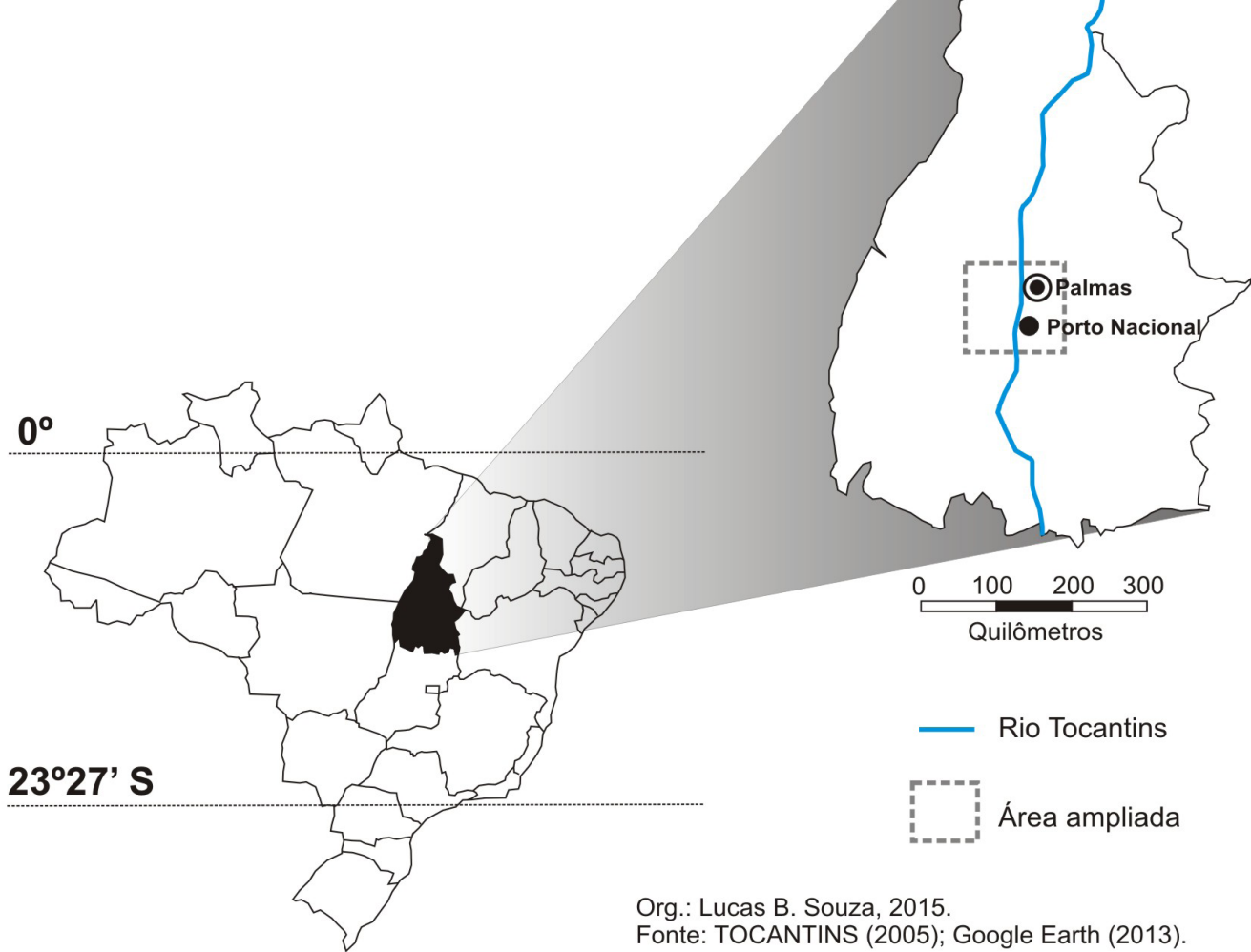

Figure 1 - Porto Nacional (TO): location and general aspects of the municipality. 
SOUZA, L. B.
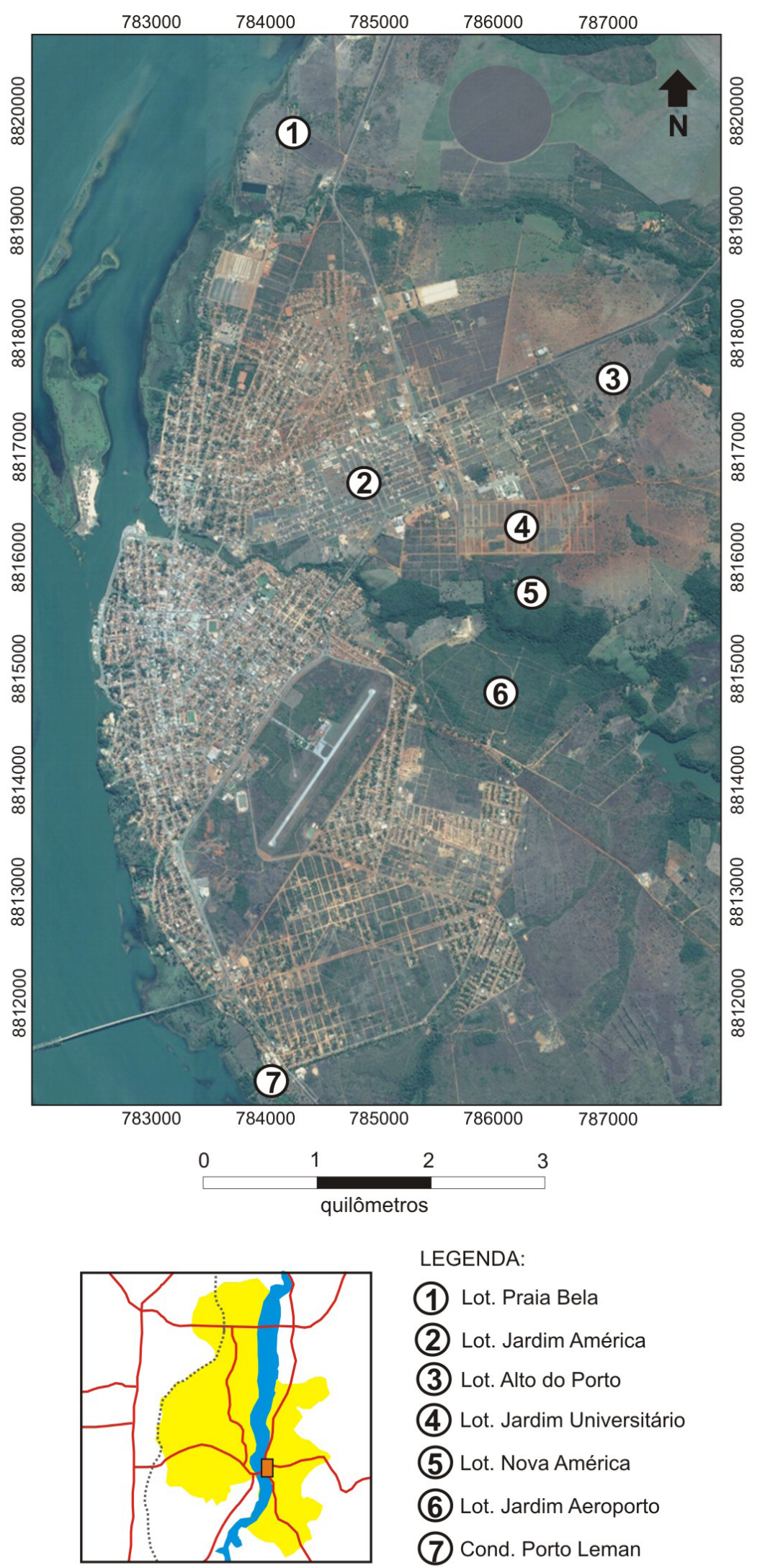

LEGENDA:

(1) Lot. Praia Bela

(2) Lot. Jardim América

(3) Lot. Alto do Porto

(4) Lot. Jardim Universitário

(5) Lot. Nova América

(6) Lot. Jardim Aeroporto

(7) Cond. Porto Leman

Área ampliada

Org. Lucas Barbosa e Souza, 2015. Fonte: Google Earth, 2013; Tocantins, 2005. Sistema de Coordenadas: UTM

Figure 2 - The urban area of Porto Nacional and the location of the principle real estate subdivisions created between 2009 and 2015. 
at a national level. This configuration has dynamized the market for new urbanized subdivisions and new housing, favoring landowners, developers, construction companies and real estate brokers. The large amount of land available on the outskirts of the city, together with a strong speculative interest has led to the formation of urban voids. This situation, combined with a historical deficit of urban infrastructure and good quality public facilities and services, has inevitably resulted in a series of environmental problems. Cities in Tocantins, especially Porto Nacional, concentrate a great variety of impacts, which exert a strong pressure on the physical-natural environment and lead to the installation of risks and injustices that affect residents in different ways and intensities.

This point of view considers the dynamics of society and nature to be inseparable, a characteristic feature of geographic discourse. More precisely, contemporary Physical Geography has sought to operationalize this inseparableness by means of the category "environment". According to Suertegaray (2009, p.112), selecting this category implies an emphasis on the dimension of the "transfiguration of nature by social practice". In turn, changes in the character of physical-natural processes lead to reactions that adversely affect society itself, even if in an unequal fashion. In this sense, nature becomes the other condition, due to benefits desired by certain social groups, whereas the misfortunes of this change often affect different groups, reinforcing its dialectic aspect .

For Casseti (1995, p.20), "the way in which nature is appropriated and transformed is responsible for the existence of environmental problems, whose origin is determined by social relationships". Therefore the mercantile character of this process is determinative for the environmental imbalance. More specifically, the urban environment, a product of urbanization, is a transfigured scenario in which the functioning of different components of the natural systems present in the urban sites is subverted. This is exemplified by disturbances: in the relationship between infiltration, surface runoff and fluvial drainage; in the quality and circulation of the air; in the balance of radiation and air temperature, among others (LOLLO; RÖHM, 2009). This transfiguration results in a series of negative impacts on the population, in particular those vulnerable groups who are relegated to the least propitious areas for occupation, devoid of amenities and threatened by natural phenomena, according to a "social division of the environment", as proposed by Acselrad (2002, p.57).

Thus, the urban environment is not just comprised of nature altered by the city, as there is essentially a plurality of themes. In the view of Rodrigues (1998), this environment begins with the appropriation and modification of nature and comes to cover everything from the urban site to the buildings. It also includes the memory, representations, legal norms and all manner of problems and contradictions that derive from its social-productive dynamic. In this way, the urban environment is the fruit or materialization of a model of society. Consequently, it would be "[...] a mistake to think that urban problems can be solved without a solution of the social question, which is the driving force and not the other way round" (SANTOS, 1994, p.113). In a similar line of reasoning, Rodrigues (1998, p.100) explains that "either the process is not understood or there is no interest in revealing the causes" (RODRIGUES, 1998, p.100).

Although it has already been studied a great deal in the geographic literature, in terms of empirical studies in Brazil, the discussion about the environmental costs of urbanization has progressed unevenly, especially in small cities. Notably, there is an accentuated disparity between the Central-Southern and the Northern regions of the country; the latter still lack studies in this field, despite the urban expansion experienced in recent years in many of its cities. In Brazil, most of the population is concentrated in small and medium-sized cities (IBGE, 2014). In Tocantins, in particular, this concentration is even more striking. Urban and environmental studies have had an important boost with the founding of the UFT (Federal University of Tocantins) in 2003; initially studies were carried out by its academic staff and subsequently by the postgraduate programs that have gradually been consolidated.

Based on the above, this text intends to bring to light the environmental implications resulting from the current model of urbanization that extends over the city of Porto Nacional, as an example of a situation that has also been verified in the principal cities of the interior of the state of Tocantins. 
The intention is not to show definitive results, but instead to problematize the theme, using part of the area in which there are powerful "modernization" processes of the territory as a reference and the aforementioned urban consequences. The aim is to draw attention to some specific features of this exaggerated model of urban expansion, examining the extensive reproduction of capital and its environmental implications. These features, usually urbanistic or political, are products of the manipulation of regulations to benefit the dominant agents, with the complicity of the instituted authorities, especially in the municipal sphere. As a geographer witnessing this disturbing process, concern about the future that is unfolding in our cities is inevitable, a fact that characterizes the dialogue upon which this text has been created.

\section{THE CURRENT MODELS OF URBAN EXPANSION: MERCANTILE CRITERIA OVERPOWER ALL THE OTHERS}

The perception of urban land as merchandise and its manipulation to accumulate capital is, invariably, the starting point for a critical interpretation of the current model of the expansion of cities. The transformation of rural land into urban land has been the focus par excellence for those who prowl around the city in search of profitability . Rolnik (2003) explains that since the Land Law, instituted by the Empire in 1850, registered purchases became the only legal way to own land in the country. The privatization of land meant that accumulating land became the main way to amass patrimony and wealth, a role previously exercised by slave ownership. Consequently, investment in real estate became seen as the safest practice, indelible before the fluctuations of the economy; any regulation that interfered negatively with its value was not well received (ROLNIK, 2003).

In this sense, there was an increase in the value of exchange to the detriment of the value of using urban land. In this respect Gonçalves (1998, p.113) explains that:

In fact, the capitalist abstracts the value of use by changing the sector of activity to suit the circumstances of the market. For him, the value of use is simply a vehicle for the value of exchange. Obviously such a phenomenon is not natural; on the contrary, it was instituted with bourgeois society. Thus, it is not surprising that the ecologist is subordinate to the economist in a society where the spread of market relations is fundamental.

In terms of exchange, the difference between rural land and urban land makes the conversion an extremely lucrative business. In the case of most of the division of land, via subdivisions, examined herein, the land owner and the company developing the land division constitute a corporation in the form of a legal entity which will administrate the undertaking. Among the situations verified, the agreed percentages for sharing the revenues are around 30 to $40 \%$ for the land owner and 60 to $70 \%$ for the developer. In the case of the former, the profits earned are worth 20 times more than the value per square meter of rural land, but the developers earn even higher profits, given the low investment in project costs, infrastructure and costs with publicity (Figure 3).

Such huge profits make it possible for the undertakings themselves to finance operations to sell lots, with down payments below $5 \%$ of the price of the lot and the remaining balance divided into up to 200 monthly installments, which are readjusted in accordance with the IGPM (General Index of Market Prices). As established in the contract, default for three consecutive months means the dissolution of the transaction; the lot is repossessed by the undertaking and any paid installments are returned to the buyer, allowing the lot to be placed on the market once more.

The costs of putting in the infrastructure required by municipal legislation and defined in the project are covered by the sums paid as down payments by buyers or, at the most, from the first monthly installments. Developers have been exempted from paying for basic obligations, such as installing sewage systems on their developments, which aggravates the chronic environmental problems typical of the Northern region of the country and leaves an immense bill to be paid by the 
community in the future. In the State of Tocantins, in general, building sewage networks on urban subdivisions is not obligatory, due to the absence of collection and treatment centers in most cities.
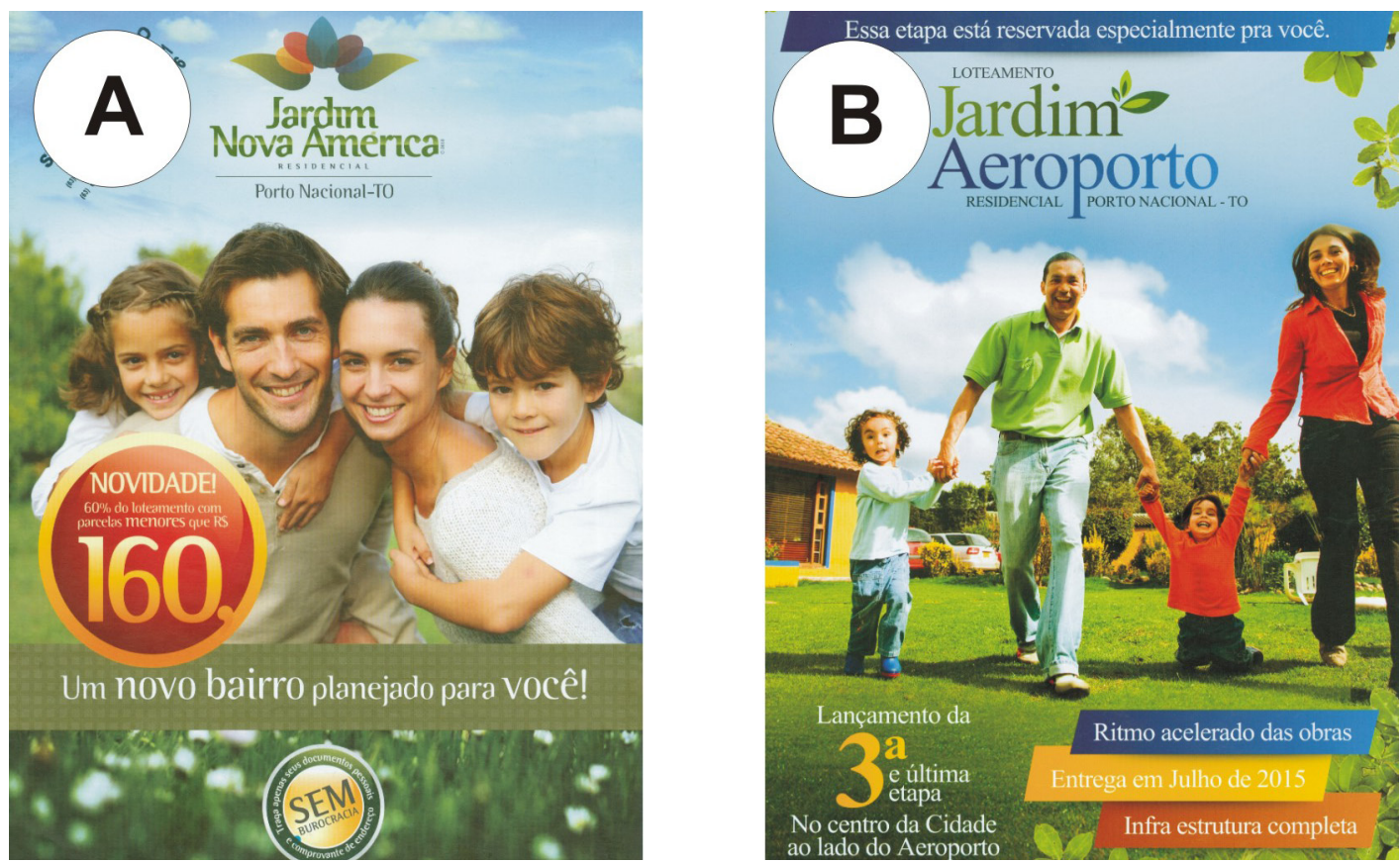

Figure 3 - Examples of publicity material for subdivisions Jd. Nova América (A) e Jd. Aeroporto (B).

A similar situation occurs with urban drainage systems, as the micro drainage in the subdivisions should be connected to the macro drainage network, although the often the latter is not adequately set up to receive the necessary interconnections. It is well known that of the four pillars of basic sanitation, according to Federal Law 11445/07 (BRASIL, 2007) - collection and treatment of sewage, management of solid waste, water supply, and urban drainage - the last is the one with the greatest deficit in Brazil. It is noteworthy that these infrastructure exemptions imposed by circumstances represent a considerable reduction in the costs of implanting subdivisions in the area in question, which further amplifies the profits made by the entrepreneurs.

At the same time, lots with reduced dimensions facilitate the sale to buyers with differing income profiles, as one or more units can be acquired. According to Pinto (2014), in the case of Porto Nacional, the law for dividing urban land (PORTO NACIONAL, 2006) established the minimum size of a lot at $360 \mathrm{~m} 2$, modifiable to $259 \mathrm{~m} 2$ in specific situations involving housing of social interest. However, the failure to define this type of housing has culminated in land deliberately being divided into $250 \mathrm{~m} 2$ lots, a fact that has become the rule in the municipality, rather than the exception (Figure 4).

Lots of this size contradict the ample availability of free areas in the municipality, almost always with a topography that favors occupation; small lots are characteristic of more densely populated cities or that ones that have a more uneven topography. This characteristic has forced a revision of urbanistic parameters related to verges, the distance between buildings, occupation and permeability rates, given the smaller size of the new lots (Figure 5).

At the same time, there has been an equal reduction in the open spaces in urban subdivisions. In 1999, a change in Federal Law 6766/79 (BRASIL, 1979), through Federal Law 9785/99 (BRASIL, 1999), made the municipalities responsible for determining the percentage of open space when dividing the land in subdivisions, ceasing to establish the minimum percentage of $35 \%$ of the plot in question, as originally defined. In Porto Nacional, this percentage is currently defined as $15 \%$, in accordance with the Law for the Division of Urban Land (PORTO NACIONAL, 2006). This change means that many of the new subdivisions do not even have plans for a public square, 
indicating a serious regression in the legislation, certainly due to the pressure from the different interested parties, with the intention of converting as much of the plot as possible into saleable lots.

Notwithstanding, purchasing lots when the subdivisions are launched takes on the aspect of a "race" to buy, with packed stands and the well-known lines of buyers waiting for their turn. It is common for the same buyer to purchase many units for speculation, either by reserving land for future sales, or through immediate resale with a premium charge to "tardy" buyers. This last practice is easily verified by the numerous advertisements for this type of sale of urban lots in Porto Nacional (Figure 6).

The sum of all these factors has led to the formation of urban voids, due to the speculative nature of the ownership of partially or completely urbanized plots of land. These urban voids result in an exaggerated horizontal expansion of the city, with implications for increased costs to install infrastructure in the future (maintenance of the pavement on public roads, providing storm drains and sewage systems etc.) and the provision of public services (garbage collection, public transport, policing etc.) (CAMPOS FILHO, 2001). The text of Porto Nacional's master plan (PORTO NACIONAL, 2007) acknowledges that these voids are a problem to be dealt with by the municipal authorities, even if in practice the opposite is true, that is, their leniency is exacerbating the problem.

When writing about the Metropolitan Region of Campinas, Bueno (2013), highlights that the oversizing of the areas intended for urban expansion puts pressure on peri-urban areas, however their rural features inflate the value of the land that can be subdivided in the future. In many cases the growth rate of the urban population does not justify setting aside such large areas for urban expansion, as defined by the municipalities' master plans. Nonetheless, speculative interest supersedes technical criteria. According to Bueno (2013, p.40), "the political importance of the landowners since colonial times has become an archaic feature of urban politics. There are few obstacles to the manipulation and expansion of urban areas and the preservation of vacant lots that are waiting for increases in real estate prices".

For Santos (1994, p.111), "the public administration itself becomes the privileged creator of scarcity; incapable of solving the housing problem it pushes most of the population to the outskirts [...]". These actions take place chiefly by manipulating, disregarding or simply failing to obey the urbanistic legislation.

For Bueno (2013, p.51), [...] there is ample literature to prove that Brazilian urbanization has been trampled on in the process of creating spaces while, historically, landowners, developers and constructors have acted with little regulation [...]. According to Sant'anna Neto (2011, p.48), “[...] in a world dominated by neoliberal thinking, the state is increasingly allowing, encouraging or even delegating control of the use of these spaces to capitalist corporations, be they public or private".

In this sense, municipalities are under pressure from speculative interests to expand their respective urban macro zones, in order to shelter new divisions of land, through subdivisions. This practice flouts Federal Law 12608/12 (BRASIL, 2012), which added article 42-B to the City Statute (BRASIL, 2001) to regulate projects to expand city limits in Brazil, using environmental criteria and standards of social justice. This type of corporate pressure has had differing degrees of success, depending on the action of the political players in each location.

In a study in the State of São Paulo, Santoro (2012) demonstrated the undeniable pressure from parties who are interested in extending the urban limits in different cities, and the different types of mechanisms employed by the municipalities, independently of the aforementioned federal law, to normalize this expansion: requirements for technical opinions by municipal secretariats and public utilities; approval from urban development councils; the need for public hearings; and the onerous granting of changes in land use.

Using Palmas as an example, according to Pinto (2014), there was a reduction in the size of the urban area during the current master plan, which was approved in 2007. In addition, there was an 


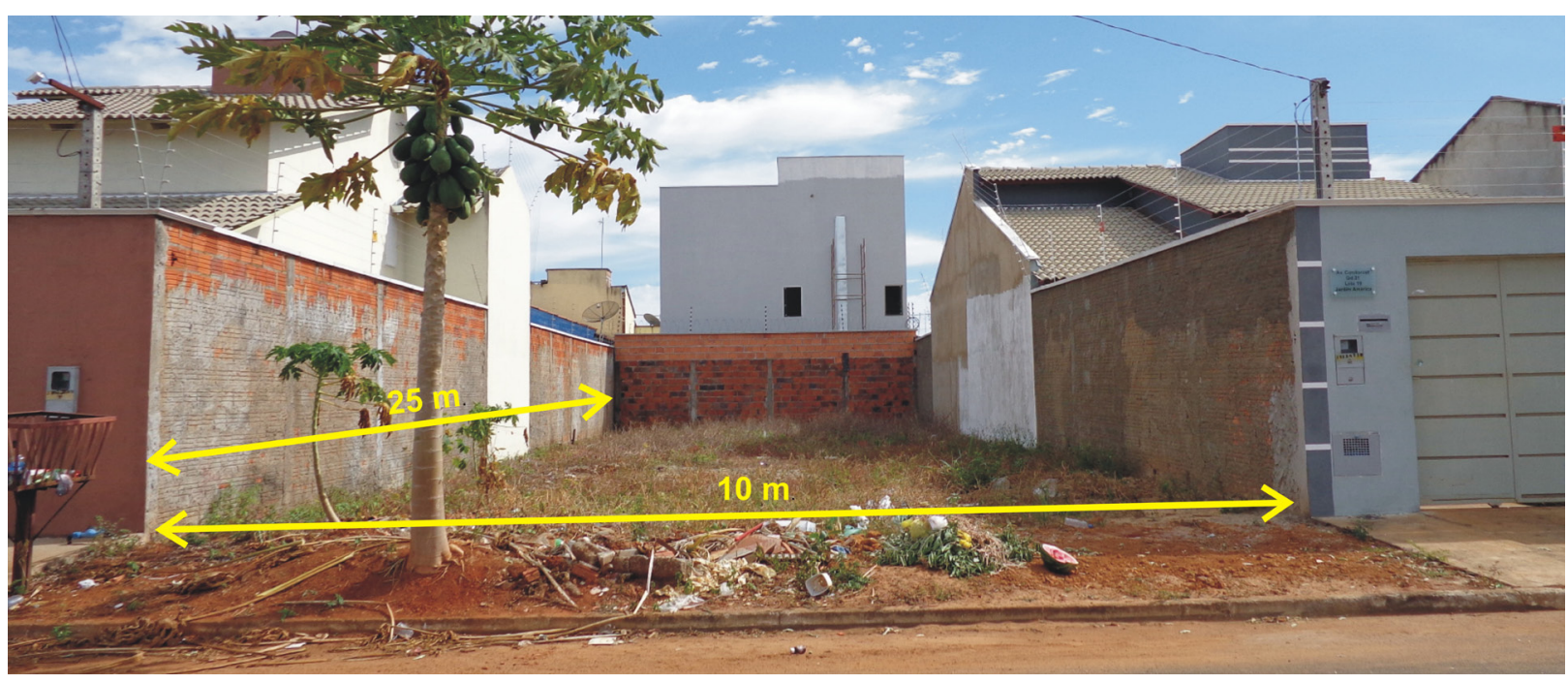

Figure 4 - A lot in Jardim América, with an area of $250 \mathrm{~m}^{2}$ Photograph: Lucas B. Souza, June/2015

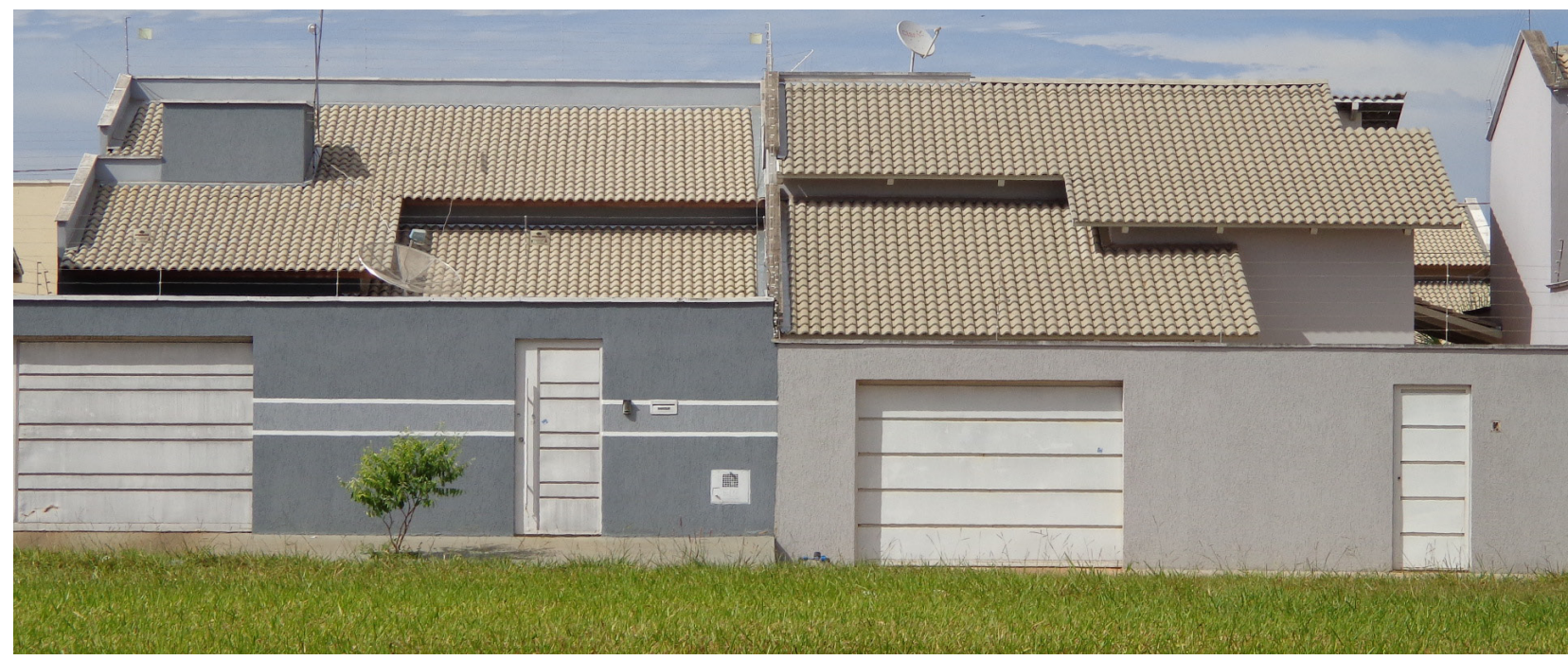

Figure 5 - Homes built in Jardim América without any space between them on the side of the lot Photograph: Lucas B. Souza, June/2015.

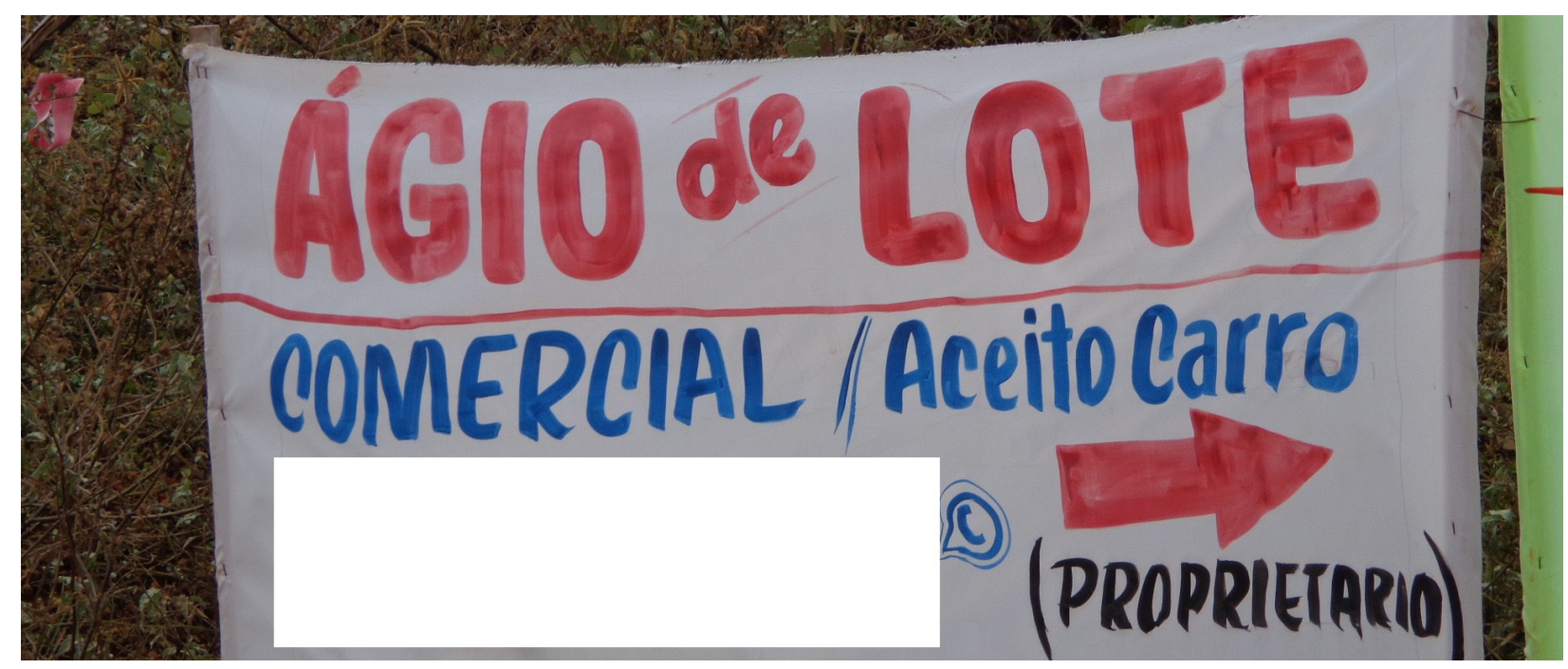

Figura 6 - Banner with an advertisement for the sale with premium charge at the Jardim Aeroporto Subdivision Photograph: Lucas B. Souza, June/2015.

MERCATR Mercator, Fortaleza, v. 14, n. 4, Número Especial, p. 159-180, dec. 2015. 
attempt to expand this area in 2011, which failed due to opposition from urban social movements, backed by researchers. This unsuccessful attempt possibly resulted in other land division strategies on the part of real estate businesses, such as investments in vertical projects in the capital itself and subdivisions in neighboring municipalities, like Porto Nacional. In the case of these subdivisions, it has been noted that the same group of companies are present at a regional or sub-regional level, working out of Palmas.

In the municipality of Porto Nacional, initiatives to modify the urban limits have not met with opposition or regulation and have been concretized to include new subdivisions, in spite of the provisions of the City Statute, through inclusions promoted in April 2012 (Lei Federal 12.608/12). At the end of that same year, Complementary Law 016/12 (PORTO NACIONAL, 2012) extended the boundaries of its principal urban macro zone, referring to the municipal center, to enable the approval of the Alto do Porto subdivision. In 2014, the same macro zone was modified once more by Law 2200/14 (PORTO NACIONAL, 2014), making the implementation of the Praia Bela subdivision possible.

In addition to these changes, the city's second urban macro zone was also extended, in the District of Luzimangues, to include new land divisions. It is noteworthy that the distance between this district and Palmas is quite small; they are only separated by the bridge that crosses the reservoir of the Luiz Eduardo Magalhães Hydroelectric Plant (Tocantins River), a fact that has driven the rapid urban expansion, in addition to fuelling the expectation of an independent municipality being created in the future. In the case of this district, the definition of the large urban macro zone, covered by the municipality of Porto Nacional's master plan, in 2007, was justified by the presence of existing scattered subdivisions, even though they were in a range of irregular and clandestine situations. This urban area would incorporate all these plots, in order to regulate their legal status (PINTO, 2014; PORTO NACIONAL, 2007). As if this classification were not enough, new areas were incorporated afterwards, in 2013 for example, by Complementary Law n.007/2013 (PORTO NACIONAL 2013a).

Indeed, the constant changes to the perimeter of urban macro zones have been the only ones necessitating approval in the municipal legislature, and requiring a more sophisticated level of coordination between stakeholders. When a plot already falls within these limits, approval for land division is merely an administrative act on the part of the municipal executive, thus restricting procedures to a more limited sphere of action. Therefore, new undertakings can be approved without any concern about the existence of an effective or immediate demand for new homes.

In this case, what can be observed is the public authorities' systematic disdain for the municipal master plan, which reduces the role of this important guiding instrument for local policies to a mere obligation enforced by the Federal Institution and the City Statute (Federal Law 10.257/01) (GUILHERME, 2014). This behavior feeds off of the interests of specific groups linked to real estate capital and the ownership of urban and peri-urban land, resulting in a lack of exclusively technical evaluations regarding urban expansion.

Furthermore, despite the progress achieved through the City Statute, municipalities are not obliged to implement some of the important planning and management tools provided for in its text, such as the IPTU (property and urban land tax) progressive over time. This fuels the need for a state of mobilization and collection at a local level that most of the population is not ready for. As demonstrated by Souza (2013), the population of Porto Nacional has very little knowledge of the concept and function of a master plan for urban development, which among other factors, seems to have contributed to the low popular participation to develop this instrument in the municipality, instituted in 2007. Coriolano et al (2013) point to a similar situation in Palmas, confirming the historical lack of political engagement of the Brazilian population with local situations, in keeping with the first-rate explanations by Souza (2003). 
Thus, lack of popular control and rudimentary participatory experiences are paths that reinforce the alienation regarding the planning and management process of urban space, the better adaptation of the city to its location and the environmental implications of this relationship. Ultimately, this hinders many Brazilian cities, such as Porto Nacional, in the State of Tocantins, from confronting and surmounting most of the urban environmental problems they face.

\section{FROM THE MERCANTILE HYPERBOLE OF URBAN EXPANSION TO ITS ENVIRONMENTAL IMPLICATIONS}

Having presented an outline of the recent model of urban expansion by means of subdivisions in the municipality of Porto Nacional, this article will now bring to light some thoughts on the environmental costs. These consequences are already evident in the form of notorious environmental impacts, as well as problems that have already been posed regarding possible future effects. To this end, consideration will be given to the links between the strategies the principle actors use to boost their profits through the urbanistic definitions of subdivision projects and their potential results in terms of the environment.

Sánchez (2008) uses CONAMA Resolution 01/86 to list the types of undertakings required to present environmental impact reports (EIR) in Brazil, a list which includes urbanistic projects over 100 hectares or those located in areas of relevant environmental interest, as defined by states and municipalities. Most of the land division projects on urban land in the State of Tocantins have smaller dimensions than the stated limit; however in Porto Nacional the municipality fails to require neighborhood impact studies (NIS), which are viable and appropriate for the urban land divisions in this area. Neighborhood impact studies are a tool that is provided to municipalities through the City Statute. According to Sánchez (2008, p.88),

The term neighborhood impact is used to describe local impacts in urban areas, such as the overload of the road system, the saturation of the infrastructure - like sewage networks or storm drains, microclimates due to shading, a high frequency and intensity of flooding because of the impermeabilization of the soil, among others.

Notable among the findings of Guilherme (2014), when investigating the application of urban environmental management tools in Porto Nacional, is the total lack of neighborhood impact studies in the municipality. According to this author, the municipal agents heard during the research were manifestly ignorant of this type of tool, a worrying fact in a city where the deliberate approval of new land divisions has been a recurring practice.

Sánchez (2008) adds that the potential generation of environmental impacts will depend on the pressure caused by the company, based on their projects' characteristics, added to the vulnerability of the natural and social features of the area in question. It is precisely this scrutiny of the adequacy between the project and local characteristics that can indicate possible impacts of the undertaking, without which the adversities will be inevitable.

Bueno (2013) considers that these adequacies have been neglected when creating urban space in Brazil, in favor of the commercial gains desired by the businesses and their potential partners:

The private planning of the creation of urban space has led to formal spatial models characterized by verticalization, the high impermeabilization of the soil, the preponderance of areas with a high thermal amplitude, and the tendency to use artificial lighting and air conditioning. [...] Public and private urban and peri-urban land planning is not based on topographical, geomorphological and geo-ecosystemic conditions when defining future land use and occupation (BUENO, 2013, p.50).

The lack of priority given to these criteria has consequences on nature and society. In this sense, taking the urban climate as an example, Sant'Anna Neto (2011) considers that the phenomenon 
can be interpreted as a social construct. Consequently, it is believed that the same reasoning can be adopted by other natural fields that comprise the urban space, such as geomorphological and bio-geographical ones.

In the context of the urban environment as a social construct, Sant'Anna Neto (2011) gives the example of the different materials used in urban buildings, showing that the poorer groups in society tend to use lower-cost materials that favor the warming of homes. It can be added that other factors vary in the same way according to social group, such as the size of lots and the implications of this: construction norms related to frontage and spacing and the possibility of tree planting inside the plots; as well as aspects related to areas used by the public such as green spaces, squares and planting street trees.

When listing the basic propositions of the urban climatic system, Monteiro (2003), points to the possibility of corrective action by humans:

The U.C.S. [urban climatic system] is admitted as capable of self-regulation, a function due to the human element, that learns about the system and is able to detect its dysfunctions, and through their decision-making ability can intervene and adapt it, using recycling devices and/or feedback systems to guide its development and growth in accordance with predetermined targets (MONTEIRO, 2003, p.25).

However, it is worth highlighting that the self-regulation mentioned by the author will preliminarily take place through political channels, as it comes up against innumerable interests linked to the ownership, commercialization and use of urban land. Therefore the technical and environmental criteria remain obscured in the face of the commercial criterion capable of interfering in the planning and management of cities, or are even disregard by of the protagonists.

When the pursuit of greater profits by large landowners and developers involves determining urbanistic legislation and the permissiveness of the municipal authorities, the negative results for the environment gain strength. The systematic reduction in the size of the lots for sale discussed above, reflects both on the actual dwelling to be built, with smaller areas planned for the gardens and yards, and the collective sum of these effects in large areas of the city (a set of buildings). A similar problem occurs with the reduction of the percentage of open spaces in the subdivisions and the absence of planned squares.

In Porto Nacional, the local climate is naturally hot all year round, due almost exclusively to the action of equatorial and tropical air masses (SOUZA, 2011; SOUZA et al, 2014). Allied to the participation of these air masses are the effects of the geographical position of the municipality, located between $10^{\circ}$ and $11^{\circ}$ latitude south, and the altitude of the urban area of between 200 and 300 meters. This means that the average monthly temperatures vary between $25.3^{\circ} \mathrm{C}$ (in July) and $28^{\circ} \mathrm{C}$ (in September), furthermore, the average maximum temperatures vary between $31.2^{\circ} \mathrm{C}$ (in March) and $35.7^{\circ} \mathrm{C}$ (in August); absolute maximum temperatures can be close to or even over $40^{\circ} \mathrm{C}$ (RAMOS et al, 2009).

These characteristics make the need for urban tree planting indisputable, both around built-up subdivisions and in public open spaces. Ferreira e Costa (2009) explain that there is no consensus among authors regarding the concept of urban green space, stating that median strips and roundabouts, which are frequently recorded as green areas, should not be included, as among other aspects they are small in size. The Brazilian Society for Urban Tree Planting (SBAU, 1996) recommends that urban environments should have at least $15 \mathrm{~m}^{2}$ of green space per inhabitant, a ratio that is unlikely to be reached in the subdivisions mentioned herein. 
Moreover, in terms of urbanistic parameters, the contraction in the size of the lots being sold imposes adaptation, with the parallel diminution of the measurements of the frontage and spacing, occupation rates and the permeability of the soil. Consequently, there is a reduction in the distance for air circulation between dwellings, a common occurrence on recent subdivisions in Porto Nacional. This is added to the removal of vegetation (Figure 7) to develop the plots and the liberal use of asphalt paving on empty or under occupied lots; these areas, with an altered albedo (GARTLAND, 2010), create urban voids for speculative purposes. These factors contribute to the creation of a city with a tendency to heat up and the formation of heat islands, as verified by empirical research by Souza et al (2012), whose results indicated intra-urban air temperature gradients close to $5^{\circ} \mathrm{C}$ under situations of atmospheric stability.

The effects on vegetation caused by the excessive division of urban land, through the reduction in the percentage of open spaces and the usual size of the lots, ultimately result in the reduction in the evapotranspiration rates. This helps aggravate the already low rates of relative air humidity that are common in the dry season of the year, which are often below $20 \%$, according to data registered in the municipality by the National Institute of Meteorology. This situation is exacerbated by the frequent burning of vegetation inside the city, much of which takes place on empty or little used plots (Figure 8). The particulate material produced and the dust from exposed soil are carried away by the wind, especially when wind speeds increase between June and September (RAMOS et al, 2009), which probably increases the incidence of respiratory diseases during the dry season of the year (GONÇALVES et al, 2012).

As if these impacts were not enough, irregular waste dumpsites are common (Figure 9), they include domestic and commercial trash and disposable items, rubble and dead animals, in the same urban voids, as has been verified in the city of Palmas by Teixeira et al (2013). These authors have corroborated that the least occupied blocks with the highest number of unoccupied plots, due to real estate speculation, have the highest number of these dumpsites, as "it can be deduced that the residents perceive these empty spaces as propitious places to discard a range of unwanted materials" (TEIXEIRA et al, 2013, p.34). In turn this favors the accumulation of water and decomposing organic materials, leading to the proliferation of illnesses caused by vectors, such as dengue fever and visceral leishmaniasis (kala-azar), both of which are recurrent in the region (SILVA, 2015). In this way, the conjunction of a variety of factors - urban voids due to real estate speculation, the population's bad habits and the omission of the public authorities in inspecting the maintenance and cleaning of empty plots - mean that the results in terms of the environment and quality of life are very discouraging.

From a pluvial and geomorphological perspective, when writing about the relation between the stages of urbanization and the acceleration of the superficial processes in urban locations, Jorge (2012) notes that the period when a city is being built is the time when there is the most erosion, 
SOUZA, L. B.

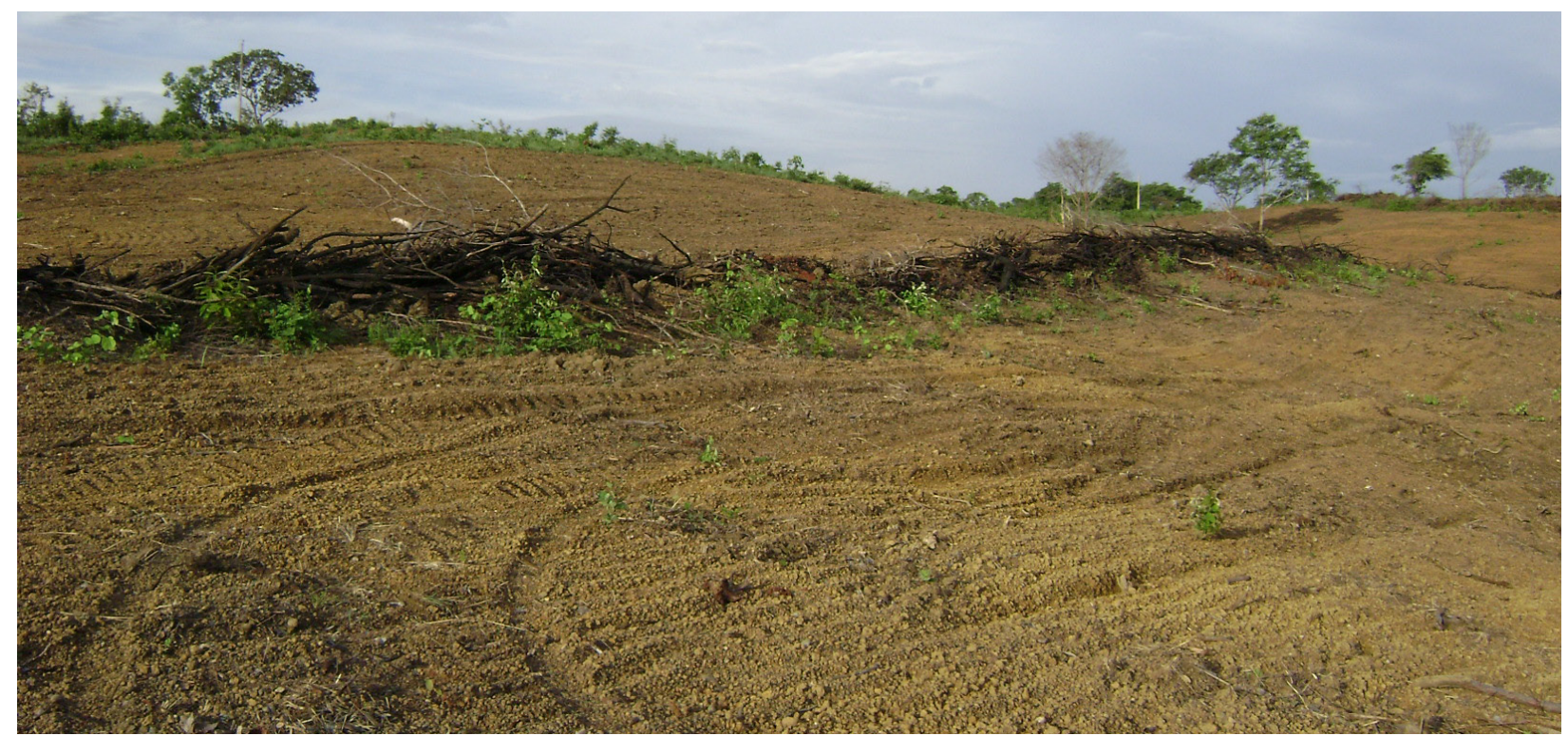

Figure 7 - The suppression of vegetation near the São João stream, to implant the Jardim América subdivision.

(Photograph: Lucas B. Souza, November/2009).

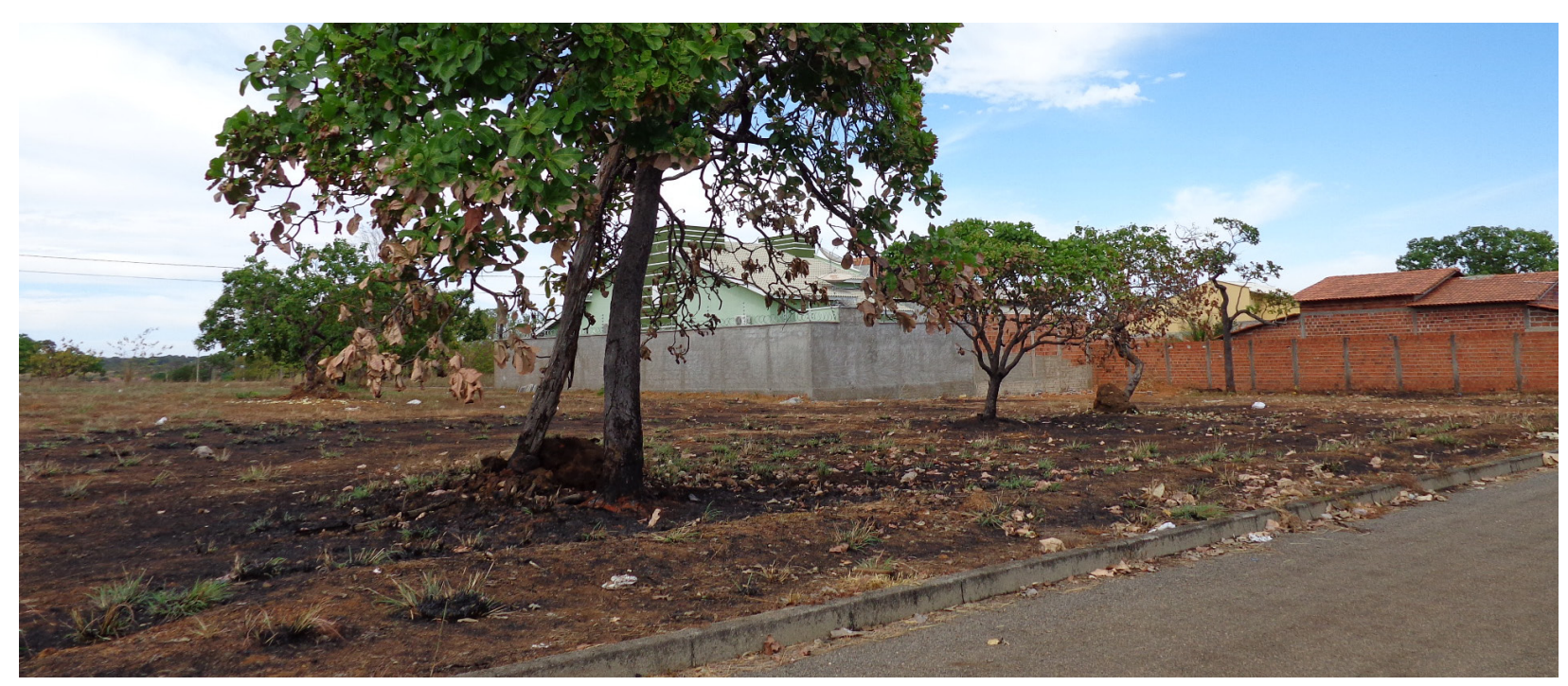

Figure 8 - Plots with indication of the burning of vegetation in the Jardim América subdivision (Photograph: Lucas B. Souza, June/2015).

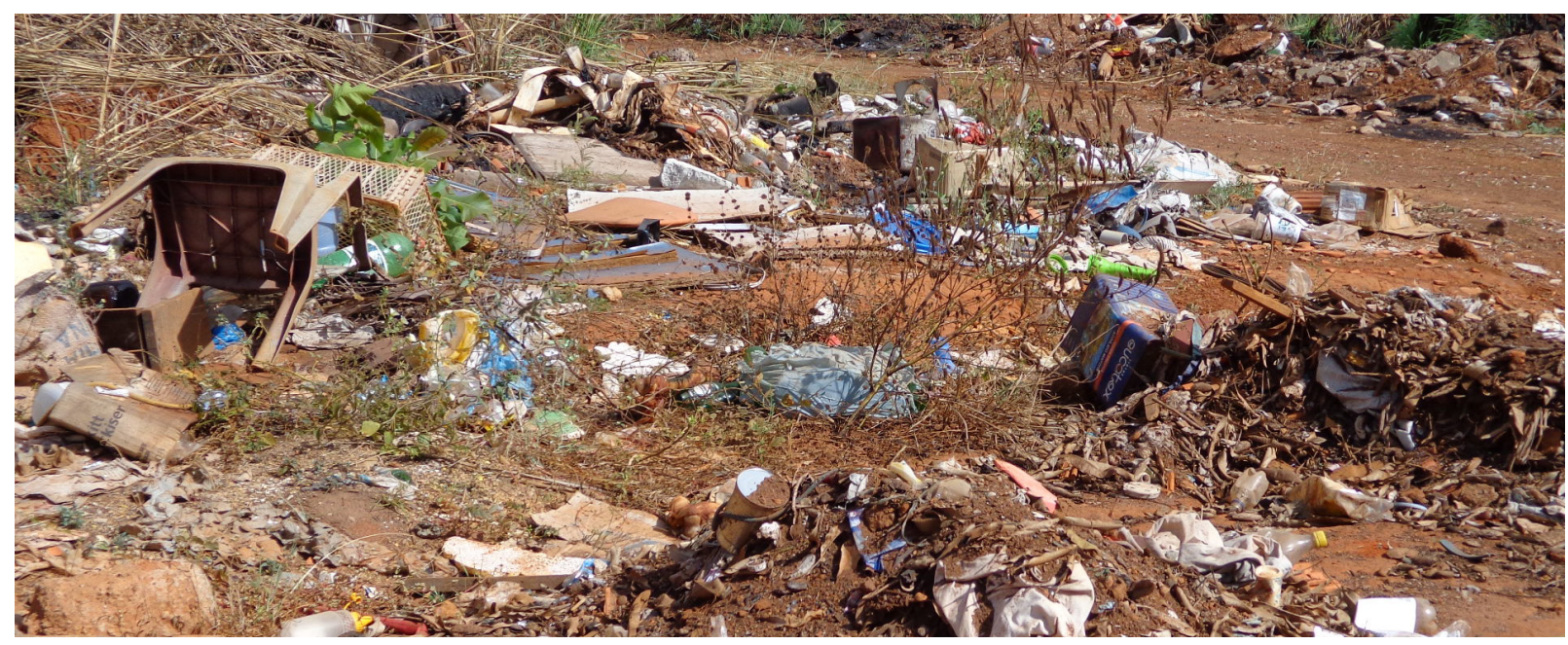

Figure 9 - A location of irregular disposal of solid waste near the Residencial Alto do Porto subdivision. (Photograph: Lucas B. Souza, June/2015). 
silting and change to the natural drainage in the plots (Figure 10). This is due to the partial or total removal of the vegetation cover, earthworks, opening up of roads, the construction of embankments and cutting into slopes. In addition, there are the works to install urban infrastructure that require excavation, such as the water supply, sewage and drainage networks.

In a city with countless new subdivisions, where there is no effective demand for urban lots, the actions above are always present and tend to be longer lasting, as the lots are occupied slowly. When the implantation stage of these subdivisions (initial works) coincide with the rainy season, it is very likely that the process of erosion and silting of the waterways are encouraged, resulting in considerable damage, as was the case in the urban stretch of the São João creek, when the Jardim America subdivision was implanted in Porto National, in the year 2009 (Figure 11). This watercourse is a direct tributary of the Tocantins River and is an important source of water for most of the city. Leite and Carvalho (2013), analyzed multi-temporal satellite images and verified a significant increase of urban occupation in the creek's basin, rising from 4.2\% in 1980 to $15.4 \%$ in 2012, which is remarkable due to the risks to its environmental quality.

In this specific example, the absence of an efficient urban drainage system has provoked the acceleration and increase in the volume of the runoff from the flow of the torrent, causing frequent flooding of public roads (Figure 12). Added to this is the complete impermeabilization of the soil by the asphalt pavement on these roads and the covered surfaces inside the lots with buildings, a characteristic that is aggravated by their restricted measurements, as explained above. Much of the rainwater supports the transport of natural and anthropic sediments, such as waste from construction, into the main channel of the São João creek, as well as causing the erosion of its banks. When it reaches the drainage network this type of solid material contributes to the reduction in its flow capacity or may even obstruct it; it also compromises the quality of the water and the live organisms that inhabit the watercourse (POLETO; MARTINEZ, 2011; TUCCI et al, 1995).

According to Guerra (2011), in urban voids or unpaved public roads many soil surfaces are exposed, intensifying laminar erosive processes and ditches. Erosion can be intensified by poorly planned storm drain systems, depending on how they are connected to the banks of river channels and may result in erosive features such as gullies. In the same way, the unsuitability of the street layout to the topographical characteristics and the soil type in the divided plots tends to potentize erosive processes (GUERRA, 2011; JORGE, 2011).

Therefore, knowing the land on which the city is expanding and designing the scenarios of the alterations to its natural processes is a fundamental task of urban environmental planning, as according to Jorge (2011, p.141), "as the socioeconomic character of a city changes there is a geomorphological response that urban policies should be aware of".

At this point, the growing vulnerability of cities to pluvial impacts is clear. The reduction of these impacts is related to the different components that interfere directly or indirectly with drainage systems: soil use and the declivity in the area of the basin; the rates of impermeabilization of the soil in public and private land; the infrastructure of the micro and macro drainage; and urban cleaning, among others. According to Sant'Anna Neto (2011), the impact of rainfall in upper and middle class neighborhoods tends to be focused on the issue of mobility, with small and transitory damage, whereas in the lower income neighborhoods these impacts cause more severe material losses, such as ruined furniture and electrical appliances, as well as possibly causing water-related diseases. 


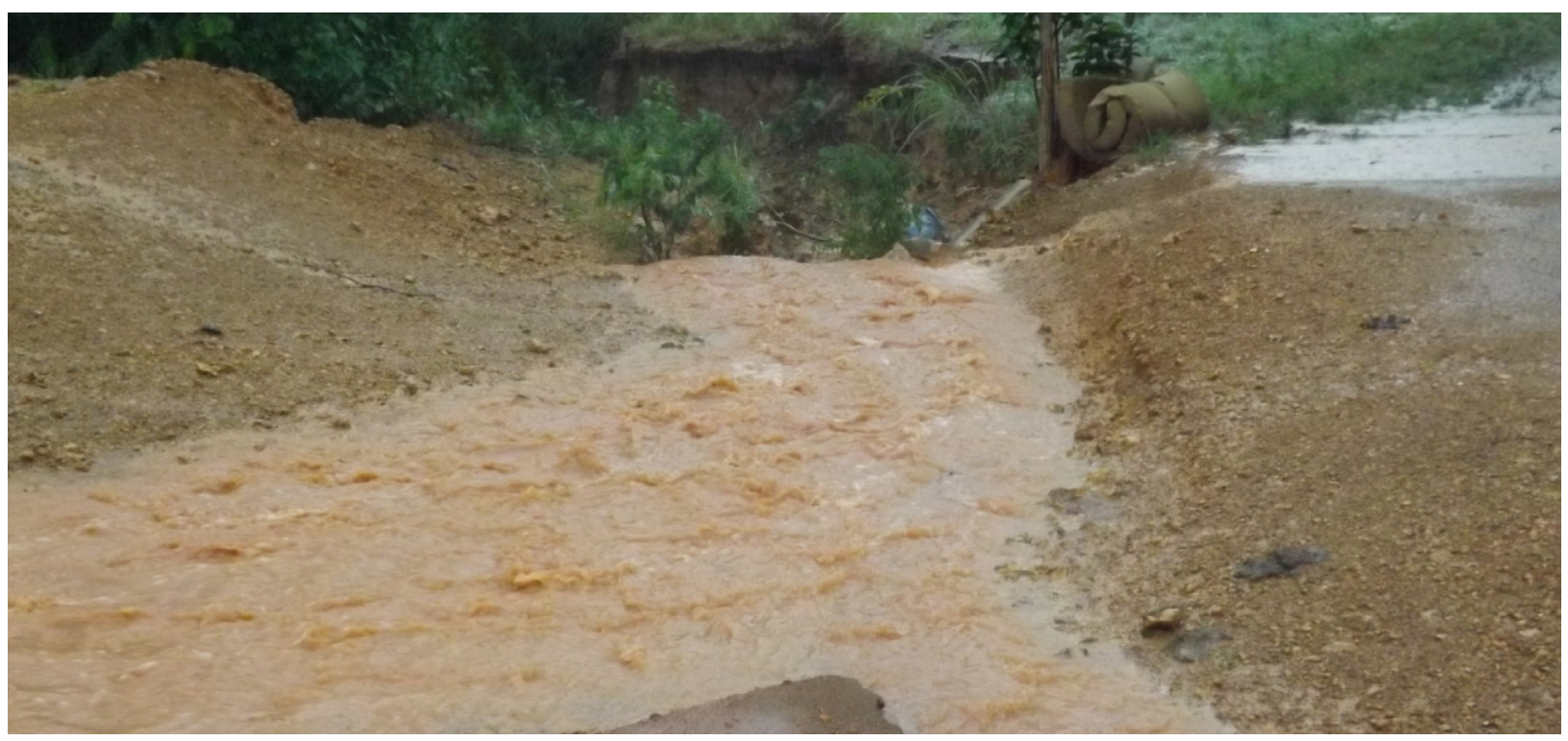

Figure 10 - Erosive feature (gully) observed during the implantation of the Jardim Nova América subdivision (Photograph: Lucas B. Souza, March/2015).

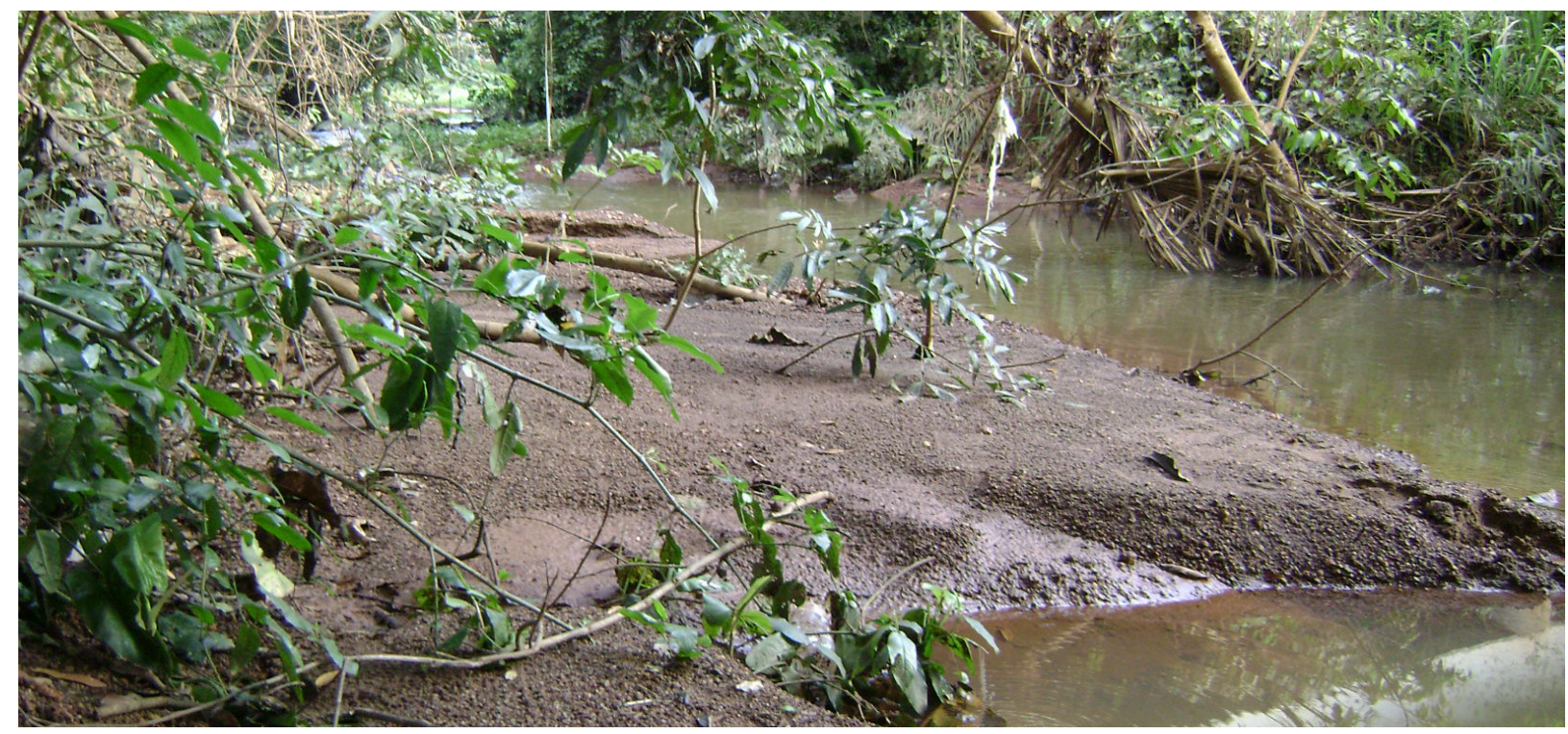

Figure 11 -Silting of the bed of the São João creek, downstream of the Jardim América subdivision, at the time of the implantation of the development (Photograph: Lucas B. Souza, November/2009).

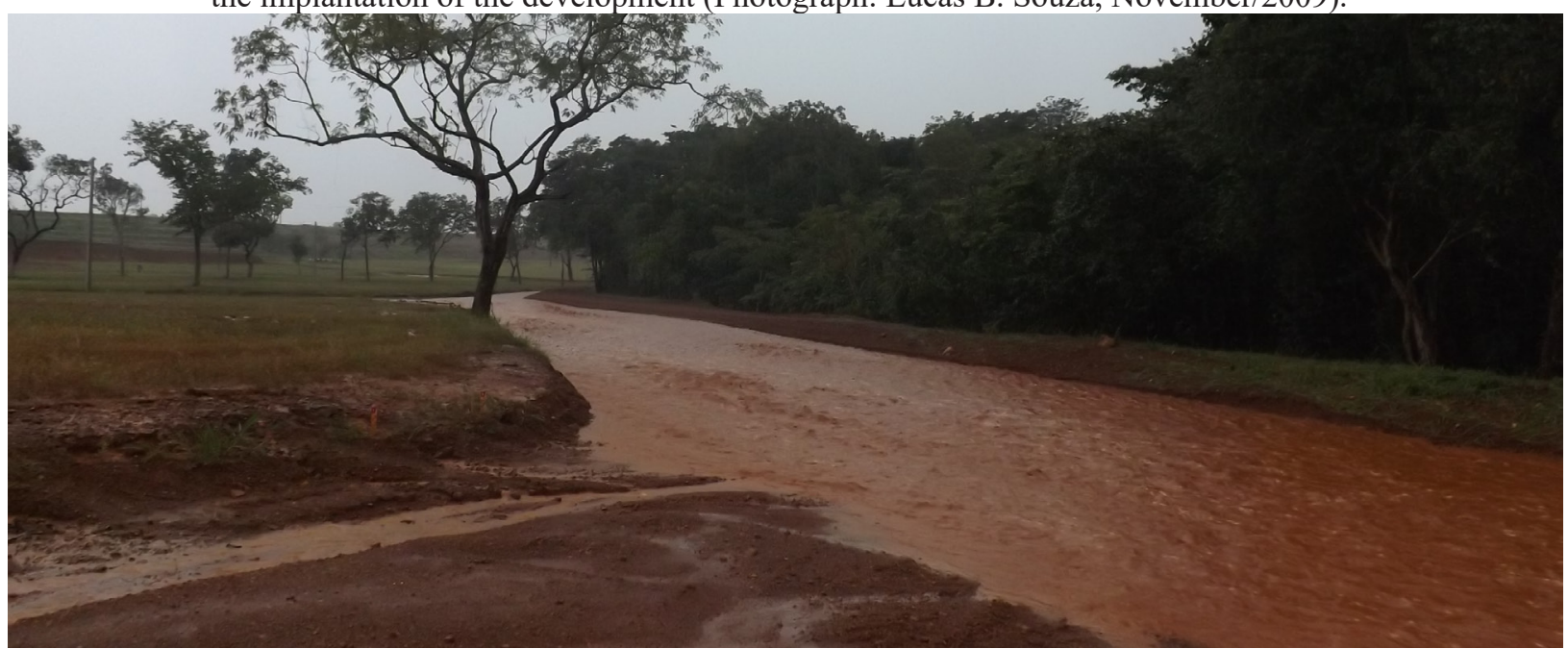

Figure 12 - A torrent, the transport of sediments and the accumulation of rainwater on a road in the Jardim Nova América subdivision (Photograph: Lucas B. Souza, March/2015). 
Continuing to use the recent implantation of subdivisions in the basin of the São João creek in Porto Nacional as an example, there are developments upstream of an older neighborhood commonly affected by flooding, called Jardim Querido (Figure 13). Rainwater drains from the subdivisions of Jardim Universitário, Nova América and Jardim Aeroporto into the aforementioned water course, increasing the load drained by the channel and escalating the risks downstream. Therefore, it can be stated that the division of urban land in an injudicious manner can both create new environmentally fragile areas, a kind of "new city" and aggravate the impacts on consolidated occupations belonging to the "old city".

As hydro-technical issues and their management have not taken into consideration the nature of local rainfall, which is characterized by its concentration in a rainy season coinciding roughly with springtime (PINTO, 2013; RAMOS et al, 2009). During the rainy season episodes of very heavy rainfall have been recorded; a quick survey of data from Porto Nacional's Weather Station (INMET) shows that between 1961 and 2010 there were 218 episodes of precipitation above $50 \mathrm{~mm}$ in a 24 hour period, 10 of which were over $100 \mathrm{~mm}$ in 24 hours. Thus, there is no way to neglect this and many other aspects from the core of urban planning, unlike current common practice.

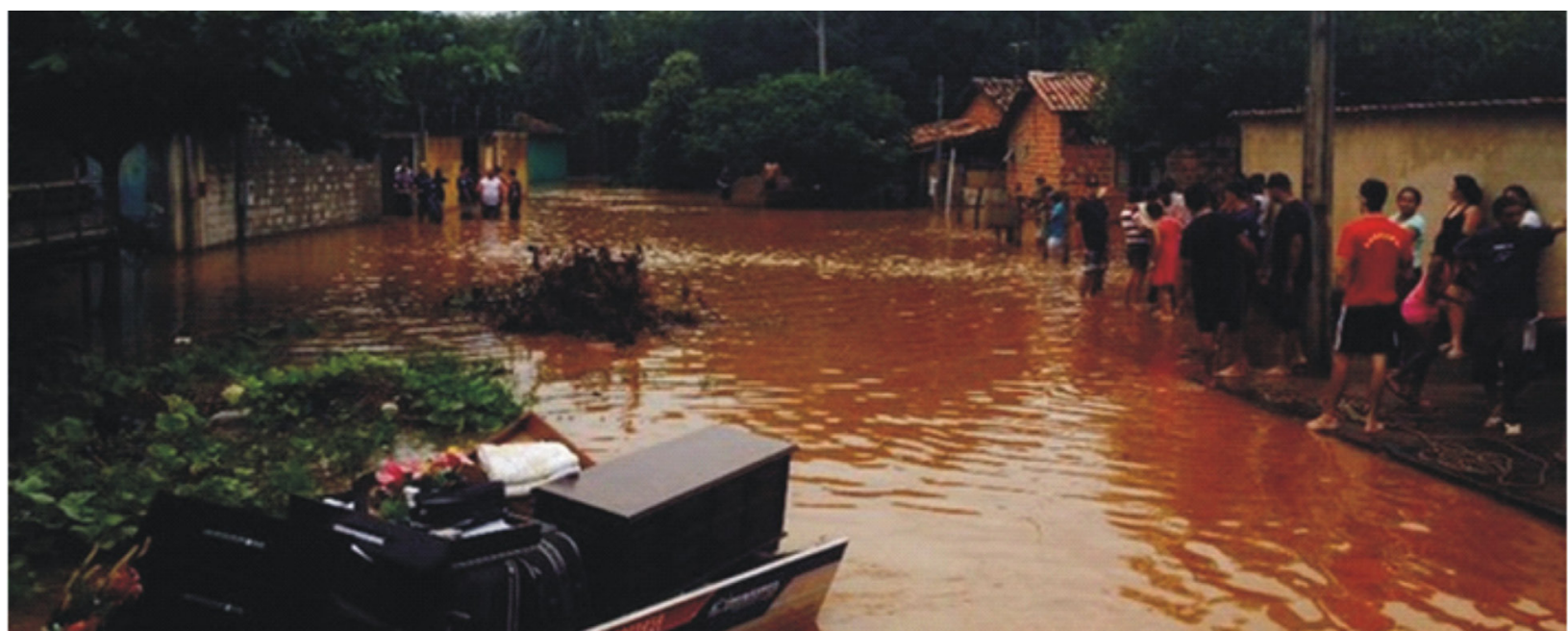

Figure 13 - An episode of flooding in the Jardim Querido Sector on the 9th March 2014 (Photograph: Alexandre Alves/TV Anhanguera/Source: <http://g1.globo.com/to/tocantins/noticia/2014/03/casas-sao-inundadas-aposbarragem-de-corrego-romper-em-porto-nacional.html> ).

All the facts problematized in this text show that discussing urban environmental problems is predominantly to speak about a transfiguration of nature originating from different strategies to generate capital in cities, through their built environment and the space still to be built upon. Specifically regarding the parceling of urban land via subdivisions, these relationships are too obvious to be ignored, leading to a wide range of unwanted effects on the resident's environment and quality of life, which go beyond the boundaries of these developments and reach neighboring districts and areas downstream in river basins, as shown in Figure 14. It is unnecessary to reaffirm that cities are conditioned by their physical base, which also conditions their environmental ills, especially when commercial and political criteria are established as the only ones worthy of effort and concern. 


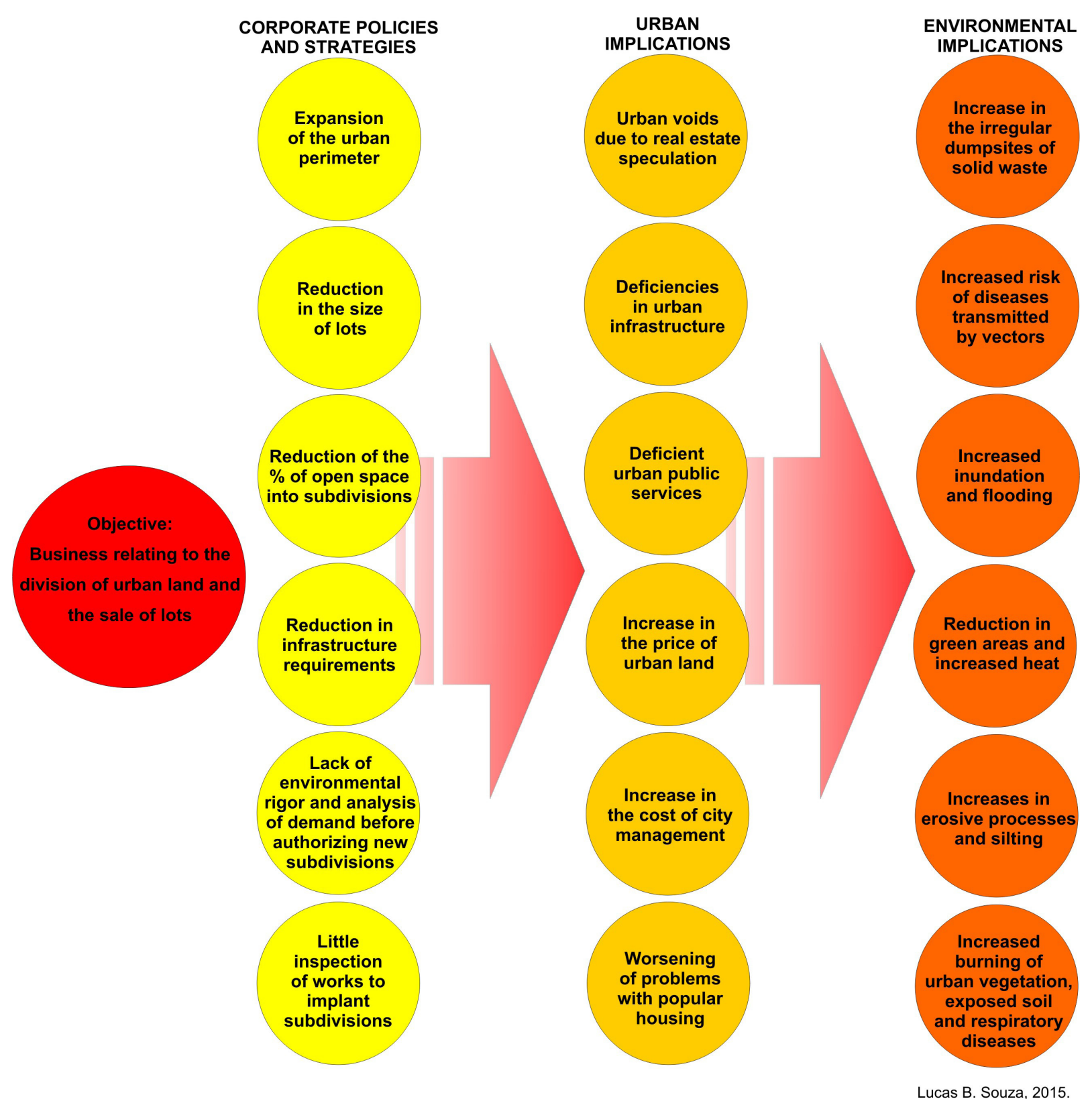

Figure 14 - Strategies and potential urban and environmental implications of the subdivisions in the study area.

\section{FINAL CONSIDERATIONS}

In our view, the current preoccupation with climate change and global warming has been focused on a scale far removed from individuals, which is a global scale. For Marandola Jr (2013, p.98), "[...] orders of magnitude beyond our perceptive capacity are potentially difficult to understand, as they depend on abstraction and conceptual frameworks for support. A global, or even national scale, is abstract for the human mind as is the microscopic scale." However, citizens' lives basically take place on a local level, which is where environmental problems are felt more directly, especially those with the greatest potential to interfere in our daily life and wellbeing. This global focus may cause local environmental themes to remain obscured or relegated to a lower plane. This favors the continuation of perverse practices such as the excessive extraction of income from urban land via subdivisions, causing an unbridled spatial expansion of cities and severe costs to fall on society.

The disorders related to the natural threats that frequently affect cities, in this way, remain much more related to the intrinsic variability of these phenomena and to the vulnerability of the urban system and its inhabitants, the latter being constructed under very well defined social and 
political circumstances (MENDONÇA et al, 2013). Climatic events are frequently related to human and economic losses in the country and are a good example of this. Tackling urban environmental problems means firstly, tackling the exclusively mercantile character of urban expansion and its social implications, as highlighted above.

Nevertheless, in the interior of Brazil, and more specifically, in Porto Nacional, the population's urban way of life is relatively recent, and its links to the countryside are still clearly seen. Thus, rural habits are still present in the city, as can be evidenced by the tree filled yards in the older neighborhoods, the rearing of animals, the vegetable gardens with medicinal plants and spices, among other customary practices. However, the impositions of the market have led to an urban expansion that results in a lifestyle that is clearly poorly adjusted to local cultural aspects. The same can be said about the physical-natural aspects of the urban location that demand adaptations to the dwellings to make them fresher and more pleasant. Such basic components of existence and human living have been systematically ignored by the groups interested in extracting income from urban land, going beyond ethical limits and ignoring the fundamental principles of citizenship, in favor of individual and corporate profit.

The varied concerns outlined above indicate the need for deeper investigation, empirical research and the monitoring of impacts, both in the city focused on in this article and in the countless others that are going through similar situations, especially on Brazil's agricultural frontier. At the same time, there is an urgent need to extend the mechanisms for popular control over the destinations and processes that are taking place in our cities, such as the interrelationships between urban expansion and environmental quality. In this sense, in addition to developing participative habits, the pedagogical aspect should also be considered, to deconstruct the recurring idea that spatial growth in cities is something invariably beneficial or desirable, a sign of development.

Specifically regarding the division of urban land, there is the aggravating factor of a vision distorted by a common understanding that new subdivisions are synonymous with progress and that acquiring an urban lot is a natural and legitimate personal financial investment, without any social or environmental consequences with collective repercussions. To end, we recur to the words of Santoro (2012, p.138), according to whom "changing the culture of the consumption of space is a great challenge by going against this model of growth". As we can see, we are facing enormous and complex challenges, in relation to which both the critical capacity and the pragmatic capacity of the geographical sciences will be essential.

\section{ACKNOWLEDGEMENTS}

To the Organizing Committee of the XIV SIMPURB, for the invitation to participate in the "The city and nature" round table and for their contribution to the dialogue between Human and Physical Geography towards a single, stronger geographical science.

\section{BIBLIOGRAPHIC REFERENCE}

ACSELRAD, H. Justiça ambiental e construção social do risco. Desenvolvimento e meio ambiente, n.5, p.49-60, jan./jun. 2002.

BESSA; K.; CORADO, V. R. A dinâmica recente do segmento de rede urbana no Tocantins: as implicações da construção de Palmas para Porto Nacional. Geotextos, v.7, n.1, 2011, p.31-57. Disponível em: http:// www.portalseer.ufba.br/index.php/geotextos/article/view/5268 Acesso em: 7 mai. 2015.

BRASIL. Lei Federal n.6.766, de 19 de dezembro de 1979. Dispõe sobre o Parcelamento do Solo Urbano e dá outras Providências. Portal da Legislação - Governo Federal. Disponível em: http://www.planalto.gov. br/ccivil_03/LeIs/L6766.htm Acesso em: 23 set. 2014.

BRASIL. Lei Federal n.9.785, de 29 de janeiro de 1999. Altera o Decreto-Lei no 3.365, de 21 de junho de 1941 (desapropriação por utilidade pública) e as Leis nos 6.015, de 31 de dezembro de 1973 (registros pú- 
blicos) e 6.766, de 19 de dezembro de 1979 (parcelamento do solo urbano). Portal da Legislação - Governo Federal. Disponível em: http://www.planalto.gov.br/ccivil_03/Leis/L9785.htm Acesso em: 23 set. 2014.

BRASIL. Lei Federal n.10.257, de 10 de julho de 2001. Regulamenta os arts. 182 e 183 da Constituição Federal, estabelece diretrizes gerais da política urbana e dá outras providências. Portal da Legislação - Governo Federal. Disponível em: http://www.planalto.gov.br/CCivil_03/leis/LEIS_2001/L10257.htm Acesso em: 1 mai. 2015.

BRASIL. Lei Federal n.11.445, de 5 de janeiro de 2007. Estabelece diretrizes nacionais para o saneamento básico; altera as Leis nos 6.766, de 19 de dezembro de 1979, 8.036, de 11 de maio de 1990, 8.666, de 21 de junho de 1993, 8.987, de 13 de fevereiro de 1995; revoga a Lei no6.528, de 11 de maio de 1978; e dá outras providências. Portal da Legislação - Governo Federal. Disponível em: http://www.planalto.gov.br/ ccivil_03/_ato2007-2010/2007/lei/111445.htm Acesso em: 1 mai. 2015.

BRASIL. Lei Federal n.12.608, de 10 de abril de 2012. Institui a Política Nacional de Proteção e Defesa Civil - PNPDEC; dispõe sobre o Sistema Nacional de Proteção e Defesa Civil - SINPDEC e o Conselho Nacional de Proteção e Defesa Civil - CONPDEC; autoriza a criação de sistema de informações e monitoramento de desastres; altera as Leis nos 12.340, de 1o de dezembro de 2010, 10.257, de 10 de julho de 2001, 6.766, de 19 de dezembro de 1979, 8.239, de 4 de outubro de 1991, e 9.394, de 20 de dezembro de 1996; e dá outras providências.Portal da Legislação - Governo Federal. Disponível em: http://www.planalto.gov. br/ccivil_03/_Ato2011-2014/2012/Lei/L12608.htm Acesso em: 1 mai. 2015.

BUENO, L. M. de M. A adaptação da cidade às mudanças climáticas: uma agenda de pesquisa e uma agenda política. In: OJIMA, R.; MARANDOLA Jr., E. (Org.) Mudanças climáticas e as cidades: novos e antigos debates na busca da sustentabilidade urbana e social. São Paulo: Blucher, 2013, p.23-56.

CAMPOS FILHO, C. M. Cidades brasileiras: seu controle ou o caos. 4 ed. São Paulo: Studio Nobel, 2001. CASSETT, V. Ambiente e apropriação do relevo. 2 ed. São Paulo: Contexto, 1995.

CORIOLANO, G. P.; RODRIGUES, W; OLIVEIRA, A. F. Estatuto da Cidade e seus instrumentos de combate às desigualdades socioterritoriais: o Plano Diretor Participativo de Palmas (TO). Urbe - Revista Brasileira de Gestão Urbana, v.5, n.2, 2013, p.131-145.

COSTA, R. G. S.; FERREIRA, C. C. M. Análise do índice de áreas verdes (IAV) na área central da cidade de Juiz de Fora, MG. Revista da Sociedade Brasileira de Arborização Urbana, v.4, n.1, 2009, p.39-57.

GARTLAND, L. Ilhas de calor: como mitigar zonas de calor em áreas urbanas. São Paulo: Oficina de Textos, 2010.

GONÇALVES, C. V. P. Os (des)caminhos do meio ambiente. 6 ed. São Paulo: Contexto, 1998.

GONÇALVES, K. S.; CASTRO, H. A.; HACON, S. S. As queimadas na região amazônica e o adoecimento respiratório. Ciência e Saúde Coletiva, v. 17, n. 6, 2012, p.1523-1532.

GUERRA, A. J. T. Encostas urbanas. In: GUERRA, A. J. T. (org.) Geomorfologia urbana. Rio de Janeiro: Bertrand Brasil, 2011, p.13-42.

GUILHERME, O. D. S. O Plano Diretor de Desenvolvimento Sustentável e a aplicação dos instrumentos de gestão ambiental na cidade de Porto Nacional - Tocantins. 2014. 113 f. Dissertação (Mestrado em Geografia), Universidade Federal do Tocantins, Campus de Porto Nacional, Porto Nacional, 2014.

INSTITUTO BRASILEIRO DE GEOGRAFIA E ESTATÍSTICA. Enciclopédia dos municípios brasileiros. Volume XXXVI. IBGE: Rio de Janeiro, 1958.

INSTITUTO BRASILEIRO DE GEOGRAFIA E ESTATÍSTICA. Cidades. 2014. Disponível em: http:// www.cidades.ibge.gov.br Acesso em: 2 mai. 2015.

JORGE, M. do C. O. Geomorfologia urbana: conceitos, metodologias e teorias. In: In: GUERRA, A. J. T. (org.) Geomorfologia urbana. Rio de Janeiro: Bertrand Brasil, 2011, p.117-145.

LEITE, E. F.; CARVALHO, E. M. Mapeamento do uso e cobertura da terra na bacia hidrográfica do ribeirão São João, Porto Nacional, Tocantins. Geoambiente, n.20, 2013, p.97-110. Disponível em: http://revistas. jatai.ufg.br/index.php/geoambiente/article/viewFile/26086/15034 Acesso em: 21 ago. 2014.

LOLLO, J. A. de; RÖHM, S. A. Loteamentos e mecanismos de avaliação de impactos no Brasil. HOLOS Environment, v.9, n.1, 2009, p.145-166. Disponível em: http://www.periodicos.rc.biblioteca.unesp.br/index. php/holos/article/view/176/2912 Acesso em: 18 mar. 2015. 
MARANDOLA Jr., E. As escalas da vulnerabilidade e as cidades: interações trans e multiescalares entre variabilidade e mudança climática. In: OJIMA, R.; MARANDOLA Jr., E. (org.) Mudanças climáticas e as cidades: novos e antigos debates na busca da sustentabilidade urbana e social. São Paulo: Blucher, 2013, p.93-113.

MENDONÇA, F. ; DESCHAMPS, M. V. ; LIMA, M. V. . A cidade e as mudanças globais: (intensificação?) Riscos e vulnerabilidades socioambientais na RMC - Região Metropolitana de Curitiba/PR. In: OJIMA, R.; MARANDOLA JUNIOR, E. (org.). Mudanças Climática e as Cidades: novos e antigos debates na busca da sustentabilidade urbana e social. São Paulo: Blucher, 2013, p. 129-152.

MONTEIRO, C. A. de F. Teoria e clima urbano: um projeto e seus caminhos. In: MONTEIRO, C. A. de F.; MENDONÇA, F. (org.). Clima urbano. São Paulo: Contexto, 2003.

PINTO, L. M. C. Luzimangues: processos sociais e política urbana na gênese de uma "nova cidade". 2012. Dissertação (Mestrado em Desenvolvimento Regional), Universidade Federal do Tocantins, Campus de Palmas, Palmas, 2012.

PINTO, L. M. C. Luzimangues: uma "nova cidade" na periferia de Palmas? Arquitextos, São Paulo, ano 14, n. 164.02, 2014, p.1-11, Disponível em: http://www.vitruvius.com.br/revistas/read/arquitextos/14.164/5019 Acesso em: 23 fev. 2015.

PINTO, P. H. P. As chuvas no estado do Tocantins: distribuição geográfica e gênese das variações rítmicas. 183 f. 2013. Dissertação (Mestrado em Geografia), Universidade Estadual Paulista, Instituto de Geociências e Ciências Exatas, Rio Claro, 2013.

POLETO, C.; MARTINEZ, L. L. G. Sedimentos urbanos: ambiente e água. HOLOS Environment, v.11, n.1, 2011, p.1-15. Disponível em: http://www.periodicos.rc.biblioteca.unesp.br/index.php/holos/article/ view/3053 Acesso em: 17 jun. 2015.

PORTO-GONÇALVES, C. V. A globalização da natureza e a natureza da globalização. Rio de Janeiro: Civilização Brasileira, 2006.

PORTO NACIONAL (Município). Lei Complementar n.07, de 2006. Dispõe sobre o Parcelamento do Solo Urbano do Município de Porto Nacional.

PORTO NACIONAL (Município). Plano Diretor de Desenvolvimento Sustentável de Porto Nacional. Porto Nacional: Prefeitura Municipal de Porto Nacional, [2007]. 1CD-ROM.

PORTO NACIONAL (Município). Lei Complementar n.016, de 11 de dezembro de 2012. Fica acrescentado o $\S 4^{\circ}$ ao Art. 86 da Lei Complementar n.05/2006 - Plano Diretor de Desenvolvimento Sustentável de Porto Nacional.

PORTO NACIONAL (Município). Lei Complementar n.007, de 12 de março de 2013. Dispõe sobre a delimitação da área para planejamento urbano futuro da macrozona urbana 02 e dá outras providências. (2013a). PORTO NACIONAL (Município). Lei Municipal n⿳ 2.132/2013, de 5 de Dezembro de 2013. Dispõe sobre a Revitalização do Ribeirão São João do Município de Porto Nacional. (2013b).

PORTO NACIONAL (Município). Lei Municipal n.2.200, de 15 de outubro de 2014. Dispõe sobre a incorporação de áreas ao perímetro urbano do Município e dá outras providências.

RAMOS, A. M.; SANTOS, L. A. R.; FORTES, L. T. G. (org.) Normais Climatológicas do Brasil 19611990. Brasília: INMET, 2009.

RODRIGUES, A. M. Produção e consumo do e no espaço: problemática ambiental urbana. São Paulo: Hucitec, 1998.

ROLNIK, R. A cidade e a lei: legislação, política urbana e territórios na cidade de São Paulo. 3 ed. São Paulo: Studio Nobel; Fapesp, 2003.

SÁNCHEZ, L. E. Avaliação de impacto ambiental: conceitos e métodos. São Paulo: Oficina de Textos, 2008.

SANFELICI, D. Financeirização e a produção do espaço urbano no Brasil: uma contribuição ao debate. Eure, v.39, n.118, p.27-46, 2013. Disponível em: http://www.scielo.cl/scielo.php?script=sci_arttext\&pid=S0250-71612013000300002\&lng=es\&nrm=iso Acesso em: 25 mai 2015.

SANT'ANNA NETO, J. L. O clima urbano como construção social. Revista Brasileira de Climatologia, v.8, p.45-60, 2011. 
SANTORO, P. F. Planejar a expansão urbana: dilemas e perspectivas. 2012. $361 \mathrm{f}$. Tese (Doutorado em Arquitetura e Urbanismo), Fac. de de Arquitetura e Urbanismo, Universidade de São Paulo, São Paulo, 2012. SANTOS, M. A urbanização brasileira. 2 ed. São Paulo: Hucitec, 1994.

SILVA, K. B. M. Leishmaniose visceral: comportamento epidemiológico e distribuição têmporo-espacial em área endêmica do Tocantins. 2015. 80 f. Dissertação (Mestrado em Ciências do Ambiente), Universidade Federal do Tocantins, Campus de Palmas, Palmas, 2015.

SOCIEDADE BRASILEIRA DE ARBORIZAÇÃO URBANA. Carta a Londrina e Ibiporã. Boletim Informativo, v.3, n,5, p.3, 1996.

SOUZA, L. B. Participação das massas de ar e suas repercussões em Porto Nacional (TO): o exemplo 2009/2012. In: MORAIS, F. (org.) Contribuições à Geografia Física do Estado do Tocantins. Goiânia: Kelps, 2011, p.179-197.

SOUZA, L. B. Planejamento urbano e participação popular: uma análise do Plano Diretor de Porto Nacional (TO). Brazilian Geographical Journal, v.4, n.1, 2013, p.12-26. Disponível em: http://www.seer.ufu.br/ index.php/braziliangeojournal/article/view/15226/12778 Acesso em: 15 jan. 2014.

SOUZA, L. B., GOMES, L. P. O., ROCHA, E. M. C. Participação dos sistemas atmosféricos no Estado do Tocantins: o exemplo do ano habitual de 2001. In: SIMPÓSIO BRASILEIRO DE CLIMATOLOGIA GEOGRÁFICA, 11; Reunião da Comissão de Climatologia da União Geográfica Internacional, 2014, Curitiba. Anais... Curitiba: Universidade Federal do Paraná, 2014. v.1. p.1533 - 1544

SOUZA, L. B. ; PINTO, P. H. P.; AZEVEDO, P. S.; SILVA, A. A. F. A temperatura do ar na área urbana de Porto Nacional (Estado do Tocantins): abordagem geográfica a partir de episódios selecionados. Brazilian Geographical Journal, v.3, n.2, 2012, p.317-350. Disponível em: http://www.seer.ufu.br/index.php/braziliangeojournal/article/view/17882/11228 Acesso em: 12 set. 2013.

SOUZA, M. L. Mudar a cidade: uma introdução crítica ao planejamento e à gestão urbanos. Rio de Janeiro: Bertrand Brasil, 2003.

SUERTEGARAY, D. M. A. Geografia física (?) geografia ambiental (?) ou geografia e ambiente (?). In: MENDONÇA, F.; KOZEL, S. (org.) Elementos de epistemologia da geografia contemporânea. Curitiba: Ed. da UFPR, 2009, p.111-120.

TEIXEIRA, D. R.; PAZ, F. N. V.; PRADO, G. L.; MARÓN, J,. R. L.; MALVÁSIO, A. Caracterização da disposição dos resíduos sólidos gerados no município de Palmas - Tocantins: um estudo de caso em quadras selecionadas. Espaço e Geografia, v.16, n.1, 2013, p.1-39. Disponível em: http://www.1sie.unb.br/espacoegeografia/index.php/espacoegeografia/article/view/157/170 Acesso em: 27 abr. 2014.

TUCCI, C. E. M.; PORTO, R. L.; BARROS, M. T. (org.) Drenagem urbana. Porto Alegre: ABRH; Editora da Universidade; UFRGS, 1995.

Submitted december 2015

Accepted january 2016 